Article

\title{
Novel Bifunctional Mesoporous Catalysts Based on Preyssler Heteropolyacids for Green Pyrrole Derivative Synthesis
}

\author{
Omar Portilla-Zúñiga ${ }^{1}$ (D) Ángel Sathicq ${ }^{1}$, José Martínez ${ }^{2}$ (D) Hugo Rojas ${ }^{2}$, \\ Eduardo De Geronimo ${ }^{3}$, Rafael Luque ${ }^{4,5, *(\mathbb{D})}$ and Gustavo P. Romanelli 1,6,*
}

1 Centro de Investigación y Desarrollo en Ciencias Aplicadas “Dr. Jorge J. Ronco” (CINDECA-CCT La Plata-CONICET), Universidad Nacional de La Plata, Calle 47 No 257, B1900AJK La Plata, Argentina; ommipz@gmail.com (O.P.-Z.); agsathicq@quimica.unlp.edu.ar (Á.S.)

2 Escuela de Ciencias Químicas, Facultad de Ciencias, Universidad Pedagógica y Tecnológica de Colombia UPTC, Avenida Central del Norte, 150003 Tunja, Boyacá, Colombia; jose.martinez@uptc.edu.co (J.M.); hugo.rojas@uptc.edu.co (H.R.)

3 Instituto Nacional de Tecnología Agropecuaria (INTA), Estación Experimental Agropecuaria, 7620 Balcarce, Buenos Aires, Argentina; edg1981@gmail.com

4 Departamento de Química Orgánica, Grupo FQM-383, Universidad de Córdoba, Campus de Rabanales, Edificio Marie Curie (C-3), Ctra Nnal IV-A, Km 396, 14014 Córdoba, Spain

5 Peoples Friendship University of Russia (RUDN University), Research Center for Molecular Design and Synthesis of Innovative compounds for the Medical Industry, 6 Miklukho-Maklaya Street, 117198 Moscow, Russia

6 CISAV. Cátedra de Química Orgánica, Facultad de Ciencias Agrarias y Forestales, Universidad Nacional de La Plata, Calles 60 y 119 s/n, B1904AAN La Plata, Argentina

* Correspondence: q62alsor@uco.es (R.L.); gpr@quimica.unlp.edu.ar (G.P.R.); Tel.: +34-95-721-1050 (R.L.); +54-221-421-1353 (G.P.R.)

Received: 6 September 2018; Accepted: 21 September 2018; Published: 26 September 2018

\begin{abstract}
In this paper, we report the synthesis of Preyssler heteropolyacids supported on mesoporous alumina in order to obtain materials with acid-base properties. A series of pyrrole derivatives were synthesized using a suitable procedure under solvent-free conditions. Using the alumina-supported material, more complex pyrrole derivatives can be obtained through a tandem one-pot process that involves the formation of 2-amino-3-cyano 4-H-chromenes by a multicomponent reaction and their subsequent conversion to pyrrole using a Paal-Knorr reaction.
\end{abstract}

Keywords: catalox SBA-90; Preyssler heteropolyacids; pyrroles; catalyst; green chemistry

\section{Introduction}

In recent times, due to the deterioration of the environment, there has been a growing interest in green chemistry, a concept that seeks a new design of processes that reduce the appearance of hazardous substances while efficiently producing compounds of interest. Anastas and Warner [1] proposed the foundations of this new way of doing chemistry.

Solvent-free synthesis processes are safer from the point of view of emissions since the use of volatile organic compounds that are a source of toxicity and increase the risk of fire and explosion is avoided. However, solvent-free reactions have disadvantages derived from the lack of molecular dynamics, mixing problems (the reaction mixture changes its consistency, and the use of the common mixing systems is not suitable), and the hazards associated with exothermic reactions. The solvent-free processes are simpler and more economical, require small reactors, reduce energy consumption, and the yields and purity of the obtained products are generally higher 
because of the greater contact between the reactants. Following this methodology, several synthetic processes have been obtained, namely, the synthesis of bis(indolyl)methanes [2], biscoumarines and 3,4-dihydropyrano[c]chromene derivatives [3], 1,4-substituted-14H-dibenzo[a,j]xanthenes [4], 5-alkoxycarbonyl-4-aryl-3,4-dihydropyrimidin-2(1H)-ones [5], propargylamines [6], aldehydes [7], and pyrrole derivatives [8].

Pyrrole is a heterocyclic aromatic core widely distributed in nature as part of different types of biological molecules involved in primary and secondary metabolism in plants and animals. The pyrrole core exists in macrocyclic systems such as porphyrin and porphyrin analogues and also as part of secondary metabolites such as eudistomines and lamerallins [9]. Many of these compounds have been used as therapeutically active drugs for centuries [10]. For this reason, pyrroles represent an important group of organic heterocyclic compounds for the production of drugs with interesting biological activities, including inhibition of HIV virus [11], antimycotic, antibacterial [12], cholesterol lowering [13], anticarcinogenic, antimalarial, and anticonvulsive drugs [14].

The Paal-Knorr reaction is a condensation process between a 1,4-dicarbonyl compound and primary amines that is generally catalyzed by a Bronsted acid or a Lewis acid (Scheme 1). The latter condition is used for molecules with easily epimerizable functions in acid media. The carbonyl compound provides the four carbon atoms in the pyrrole core, while the amine provides the nitrogen atom [15]. However, the reaction is limited to amines that do not have $\alpha$-alkyl substituents, such as cyclohexylamine [16]. The mechanism of the reaction involves the double condensation of the amine with the carbonyl compound in one of two possible ways and follows equivalent steps regardless of whether it is catalyzed by a Lewis acid or a Bronsted acid. Mechanically, this synthetic process is simple, but it has a high versatility that depends on the type of carbonyl and amine used. This allows for a wide range of modifications and improvements, from the use of different types of Lewis acid catalysts and biodegradable catalysts [17], through unusual solvents such as ionic liquids [18], and to the use of activation techniques such as microwaves (MW) [19] and ultrasounds (US) [20].<smiles>[R]C(=O)CCC(=O)[PH2+]N</smiles>

Scheme 1. Paal-Knorr pyrrole synthesis.

Catalytic processes using heteropolyacids (HPAs) as solid acid catalysts have many advantages over catalysis using liquid acids. HPAs are noncorrosive, inexpensive, and eco-compatible, with fewer disposal problems. Their reuse is possible, and they are easier to separate from liquid products than homogeneous catalysts [21,22].

Heteropolyacids can chemically be defined as molecular clusters notable for their structural diversity and acidic and electronic properties. These compounds are complex protonic acids incorporating polyoxometallic anions (heteropolyanions) with metal-oxygen octahedra as basic structural units. The $\left[\mathrm{NaP}_{5} \mathrm{~W}_{30} \mathrm{O}_{110}\right]^{14-}$, known as the Preyssler anion, is a large structure that encrypts a Na+ cation in its central cavity. This cavity is formed by five $\mathrm{PW}_{6} \mathrm{O}_{22}$ units derived from the Keggin anion ( $\left[\mathrm{PW}_{12} \mathrm{O}_{40}\right]^{3-}$ ) that have been modified by the removal of two sets of three octahedra of $\mathrm{WO}_{6}$ from the shared corners. In the solid state, the anion behaves like a pure Bronsted acid, being a stronger acid than the conventional solid acids such as $\mathrm{SiO}_{2}-\mathrm{Al}_{2} \mathrm{O}_{3}$ and zeolites $\mathrm{HX}$ and $\mathrm{HY}$ [23].

Preyssler heteropolyacids have been used mainly as acid catalysts in the synthesis of esters [24], tetrazines [25], ethers [26], pyrimidinones [27], pyranopyrazoles [28], etc. In this case, the polyoxometalate is supported on fibers such as cellulose acetate or chitosan to obtain composites [29-31]. Other heteropolyacids have also been supported on different matrices, such as silica gel [32,33], carbon [34], and clays [35], and the supported catalysts that are obtained have been used in different reactions, all of them acid catalysis reactions, such as those for obtaining the pyrrole core in tricomponent reactions [36], the Clauson-Kaas reaction [37], and from condensation [38]; in all of these processes, the yields are 
high, the supported catalyst is usually more active than the active bulk active phase, and the catalyst recovery favors several cycles of use. However, reports of heteropolyacids supported on alumina are scarce $[26,39]$ due to the acid-base reaction that can occur on the surface of this type of support because of the basic behavior of their surface $[40,41]$. In this work, an attempt was made to develop a bifunctional heteropolyacid-alumina catalyst with the aim of using it both in the synthesis of a series of pyrroles derived from amines and in the synthesis of aminochromenes that were functionalized with the pyrrole core.

\section{Results and Discussion}

\subsection{Catalyst Characterization}

\subsubsection{Textural Properties}

The specific surface areas of the bulk catalysts $\mathrm{PWAl}_{2} \mathrm{O}_{3}$ and $\mathrm{PWMoAl}_{2} \mathrm{O}_{3}$, obtained by $\mathrm{N}_{2}$ adsorption-desorption, are too low $\left(<10 \mathrm{~m}^{2} / \mathrm{g}\right)$, which is essentially typical of nonporous materials (Table 1). In the case of supported catalysts, the difference in surface area between the support and the catalyst is not significant, since the active phase load is very small and the pore size is quite large due to the inherent mesoporosity of the alumina material.

Table 1. Textural properties of bulk and supported catalysts.

\begin{tabular}{cccc}
\hline Catalyst & $\mathbf{S}_{\boldsymbol{B E T}}\left(\mathbf{m}^{2} / \mathbf{g}\right)$ & Pore Volume $\left(\mathbf{c m}^{3} / \mathbf{g}\right)$ & Pore Size $(\mathbf{n m})$ \\
\hline $\mathrm{PW}$ & $<10$ & - & - \\
$\mathrm{PWMo}$ & $<10$ & - & - \\
$\mathrm{Al}_{2} \mathrm{O}_{3}$ & 106 & 0.3 & 14.6 \\
$\mathrm{PWAl}_{2} \mathrm{O}_{3}$ & 101 & 0.3 & 13.2 \\
$\mathrm{PWMoAl}_{2} \mathrm{O}_{3}$ & 110 & 0.3 & 12.1 \\
\hline
\end{tabular}

\subsubsection{Fourier Transform-Infrared Spectroscopy}

IR spectra of the Preyssler acid (PW) show an asymmetric stretching vibration of the terminal oxygen at $970 \mathrm{~cm}^{-1}$ and the $\mathrm{P}-\mathrm{O}$ asymmetric stretching frequency at 1090 and $1163 \mathrm{~cm}^{-1}$. In PWMo, the asymmetric stretching vibration for the terminal oxygen shifts to 1088, and the $\mathrm{P}-\mathrm{O}$ stretching is observed at $958 \mathrm{~cm}^{-1}$. The vibration at $1163 \mathrm{~cm}^{-1}$ is weak due to the change of symmetry in the structure by the Mo atom. Both bulk catalysts have vibrations at $940-913 \mathrm{~cm}^{-1}$ for $\mathrm{W}-\mathrm{O}-\mathrm{W}$ stretching, at $772-777 \mathrm{~cm}^{-1}$ for $\mathrm{W}=\mathrm{O}$ stretching, and at $525 \mathrm{~cm}^{-1}$ for $\mathrm{P}-\mathrm{O}$ bending $[23,25,30]$ (Figure 1). When these active phases are supported on Catalox SBa-90, the main bands remain but shift to lower wavenumbers probably because of the acid-base interaction with the alumina surface.

a)

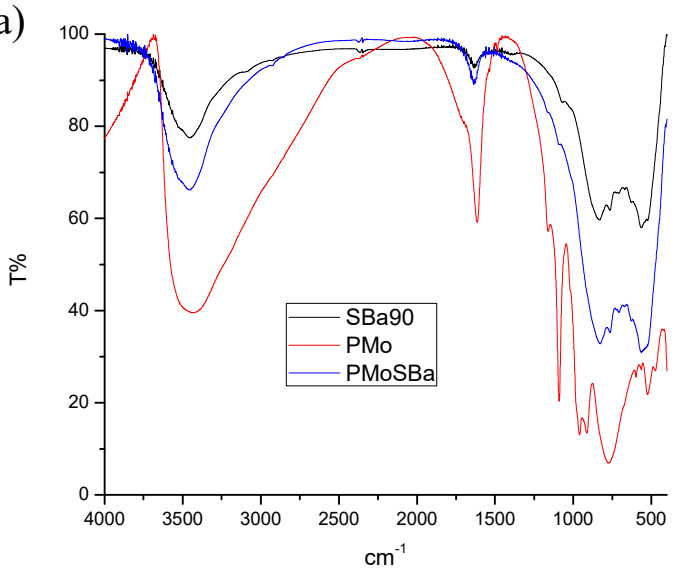

b)

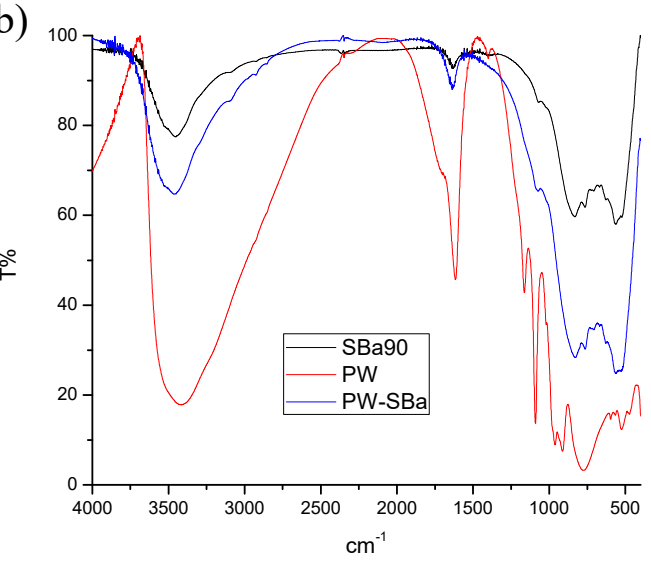

Figure 1. FT-IR spectra of the support, active phase, and catalysts; (a) $\mathrm{Al}_{2} \mathrm{O}_{3}$ (black), PWMo (red) and $\mathrm{PWMoAl}_{2} \mathrm{O}_{3}$ (blue); (b) $\mathrm{Al}_{2} \mathrm{O}_{3}$ (black), $\mathrm{PW}$ (red) and $\mathrm{PWAl}_{2} \mathrm{O}_{3}$ (blue). 


\subsubsection{In Situ FT-IR Analysis of Pyridine (py) Adsorption and Desorption}

The nature of the acid sites was determined for $p y$ absorption. PW and PWMo show a strong absorption band near $1484 \mathrm{~cm}^{-1}$ related to Bronsted-Lewis sites. Nevertheless, at $1634 \mathrm{~cm}^{-1}$ (pure Bronsted sites) or at $1591 \mathrm{~cm}^{-1}$ and $1442 \mathrm{~cm}^{-1}$ (pure Lewis sites), no bands appear. By contrast, these bands appear in Catalox SBa-90 (Figures 2 and 3). The results indicated that Bronsted sites in the supported catalyst should be contributed mainly by heteropolyacid species. However, in the supported catalyst, only the bands at 1597 and $1451 \mathrm{~cm}^{-1}$ appear, which means that the acid sites in $\mathrm{PWAl}_{2} \mathrm{O}_{3}$ and $\mathrm{PWMoAl}_{2} \mathrm{O}_{3}$ are mostly Lewis sites [26]. This can be explained by the small amount of active phase on the support, which promotes the acid-base reaction (neutralization) between the alumina surface and the heteropolyacid protons that removes Bronsted sites. However, it is not possible to ensure that the presence of Preyssler acids on the support has no effect on the Paal-Knorr reaction since the yields using only the support are below those obtained with $\mathrm{PWAl}_{2} \mathrm{O}_{3}$ and $\mathrm{PWMoAl}_{2} \mathrm{O}_{3}$.

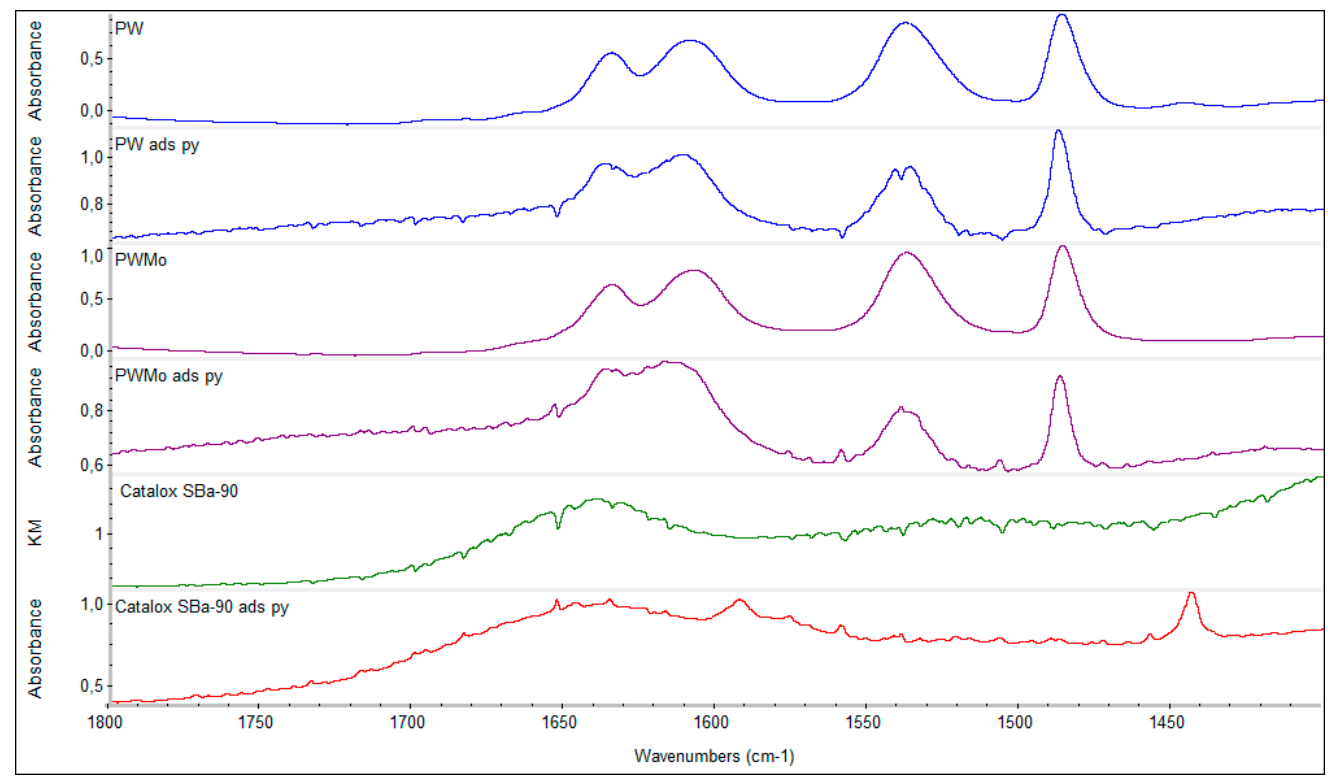

Figure 2. FT-IR spectra of pyridine adsorption (ads py) on PW, PWMo, and Catalox SBa-90.

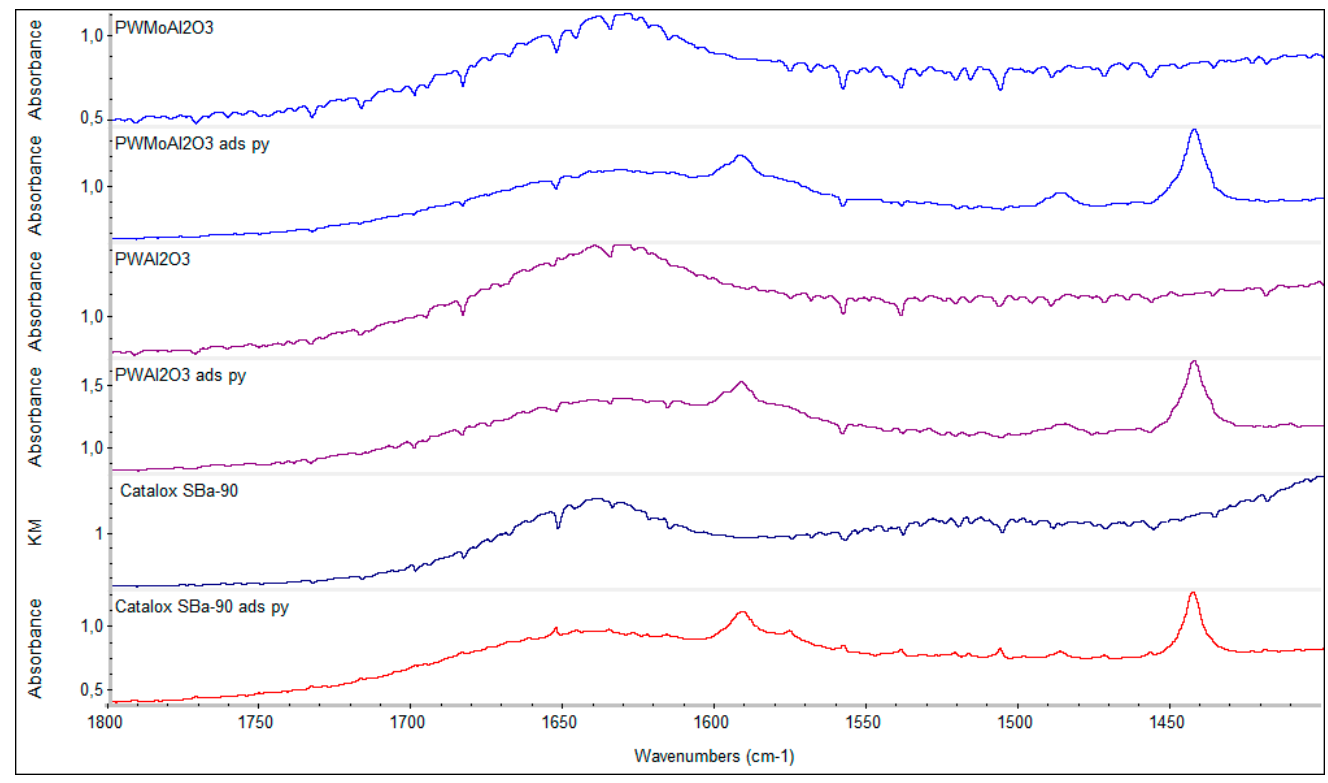

Figure 3. FT-IR spectra of pyridine adsorption on Catalox-SBa90, $\mathrm{PWAl}_{2} \mathrm{O}_{3}$, and $\mathrm{PWMoAl} \mathrm{O}_{3}$. 


\subsubsection{Potentiometric Titration}

Table 2 shows the initial electrode potential (Ei) for the catalysts. All the species have very strong acid sites compared to those found in $\mathrm{Al}_{2} \mathrm{O}_{3}$. The bulk PW and PWMo have the strongest acid sites in the catalyst series. The results show that the supported species decrease their acid strength. This per se indicates that the alumina surface is responsible for modulating the strength of the PW and PWMo. This behavior is related to the loss of Bronsted sites in $\mathrm{PWAl}_{2} \mathrm{O}_{3}$ and $\mathrm{PWMoAl}_{2} \mathrm{O}_{3}$ observed in pyridine adsorption tests.

Table 2. Initial electrode potential (Ei) for the catalysts.

\begin{tabular}{cc}
\hline Catalyst & $\mathbf{E} \boldsymbol{i}(\mathrm{U} / \mathbf{m V})$ \\
\hline $\mathrm{PW}$ & 779 \\
$\mathrm{PWMo}$ & 657 \\
$\mathrm{Al}_{2} \mathrm{O}_{3}$ & 74 \\
$\mathrm{PWAl}_{2} \mathrm{O}_{3}$ & 497 \\
$\mathrm{PWMoAl}_{2} \mathrm{O}_{3}$ & 452 \\
\hline
\end{tabular}

\subsubsection{SEM and EDX Spectra}

To verify that the heteropolyacid was supported on the alumina surface, we recorded the EDX spectra of the active phase (Figure 4) support and both catalysts (Figure 5); in the spectrum of the support, a clear $\mathrm{Al}$ peak appeared (a). In the case of the $\mathrm{PWAl}_{2} \mathrm{O}_{3}$ catalyst, we observed $\mathrm{Al}, \mathrm{P}, \mathrm{Na}$, and $\mathrm{W}(\mathrm{b})$. $\mathrm{PWMoAl}_{2} \mathrm{O}_{3}$ includes the Mo peak (c). The mapping of the catalyst shows the high dispersion of the active phase on the alumina surface for both catalysts (Figures 6 and 7).
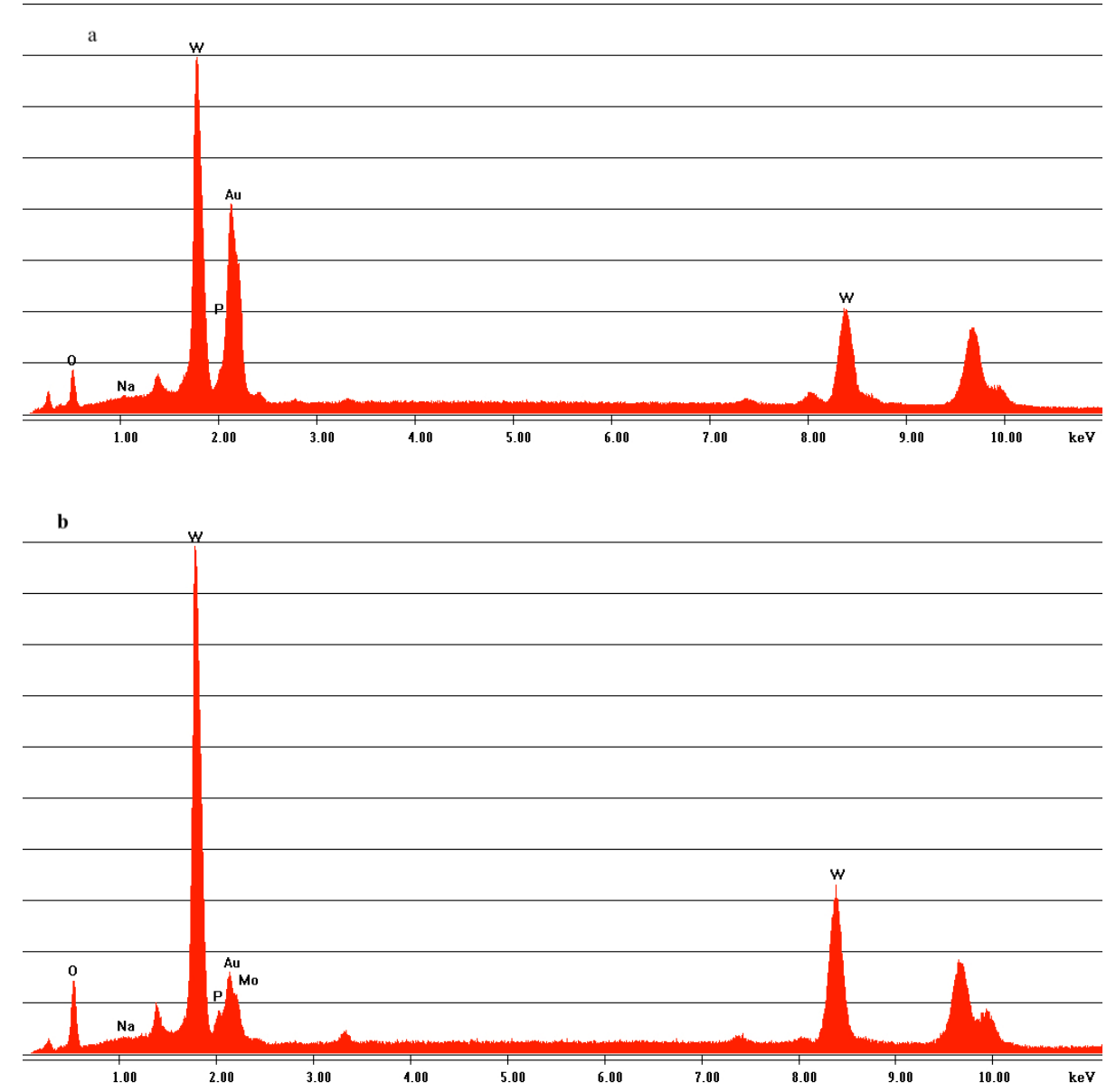

Figure 4. EDAX spectra of (a) PW, (b) PWMo. 

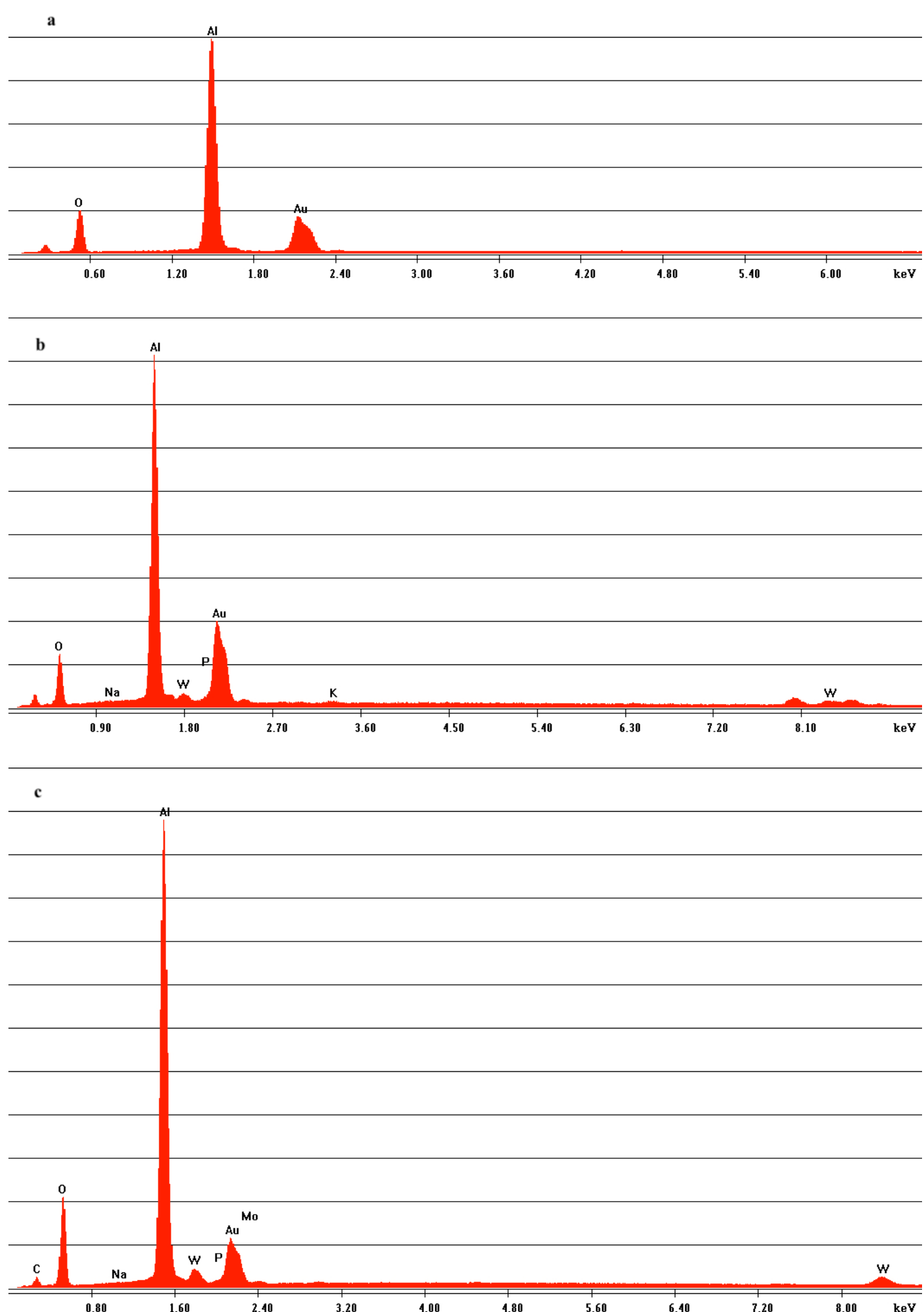

Figure 5. EDAX spectra of (a) Catalox Sba-90, (b) $\mathrm{PWAl}_{2} \mathrm{O}_{3}$, and (c) $\mathrm{PWMoAl}_{2} \mathrm{O}_{3}$. 

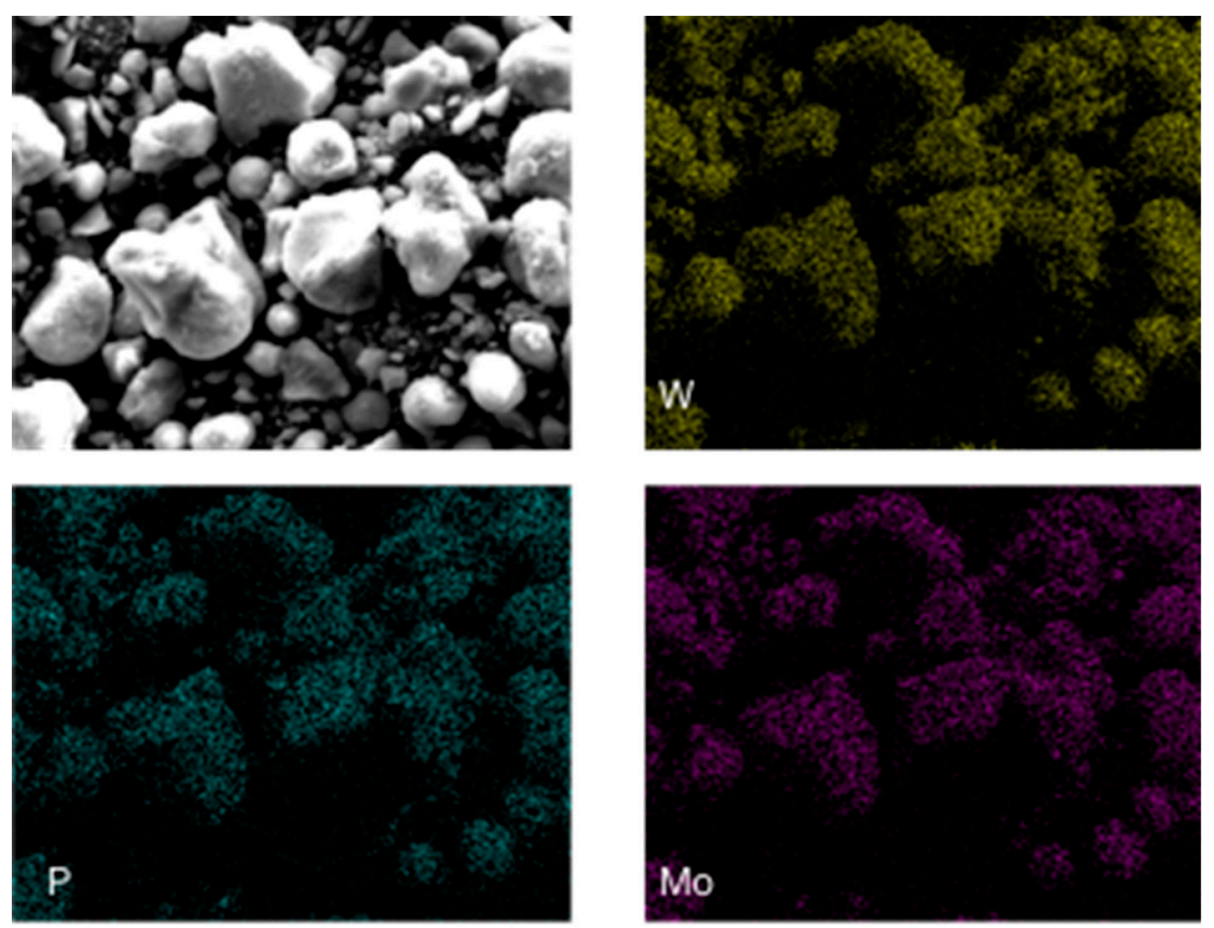

Figure 6. SEM micrographs of $\mathrm{H}_{14} \mathrm{NaP}_{5} \mathrm{~W}_{29} \mathrm{MoO}_{110}$ /Catalox SBa-90, mapping of $\mathrm{W}, \mathrm{P}$, and Mo.
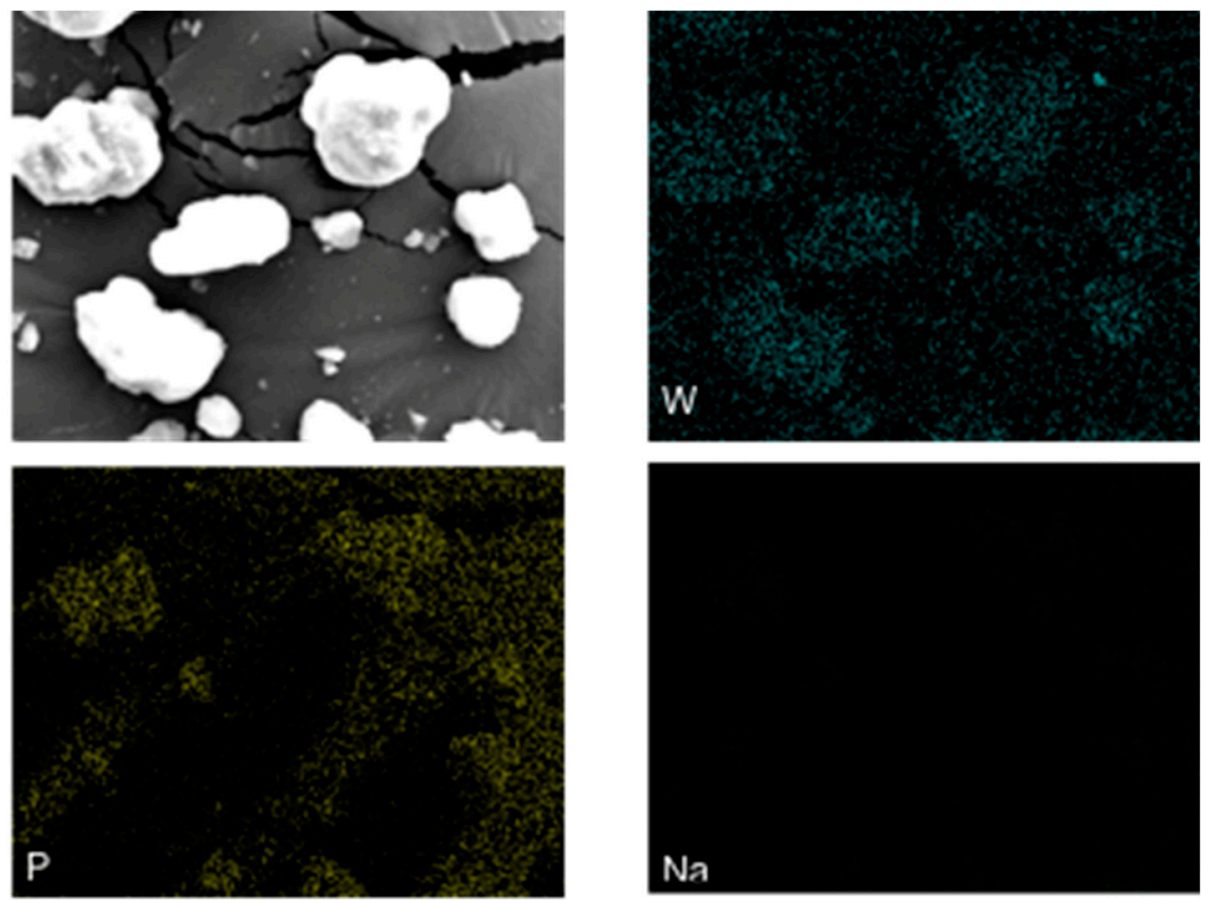

Figure 7. SEM micrographs of $\mathrm{H}_{14} \mathrm{NaP}_{5} \mathrm{~W}_{30} \mathrm{O}_{110} /$ Catalox SBa-90, mapping of $\mathrm{W}, \mathrm{P}$, and $\mathrm{Na}$.

\subsection{Catalytic Tests}

Optimum reaction conditions were studied employing 4-toluidine and acetonylacetone as a test reaction under solvent-free conditions at $60{ }^{\circ} \mathrm{C}$ for $45 \mathrm{~min}$ to obtain the pyrrole derivative (Scheme 2). 
<smiles>CC(=O)CCC(C)=O</smiles><smiles>[R]c1ccc([R])n1-c1ccc(C)cc1</smiles>

Scheme 2. Test reaction between 4-toluidine and acetonylacetone.

First, in a blank experiment, in the absence of catalyst, a moderate yield (47\%) of $\mathrm{N}$-(4-methylphenyl)2.5-dimethylpyrrol was obtained (Table 3, entry 1). The bulk Preyssler heteropolyacid (PW) was then checked under similar conditions (Table 3, entry 5). In the experiment, excellent yields of product 3 were obtained $(98 \%)$, indicating that the presence of a catalyst with acid properties is necessary to improve the reaction yields.

A key factor in the yield of this reaction is the amount of PW catalyst. Table 3 shows the results when different proportions of the catalyst were used at the previously defined reaction temperature and time. It can be seen that $40 \mathrm{mg}$ of PW gave practically quantitative yields (98\%, Table 3, entry 5) and no important changes were observed when the catalyst amount was increased to $80 \mathrm{mg}(85 \%$, Table 3, entry 6).

Table 3. Effect of different catalyst amounts of PW on product yields (\%). Reaction conditions: 4-toluidine $(1 \mathrm{mmol})$; acetonylacetone $(1 \mathrm{mmol})$; $\mathrm{PW}$ catalyst; solvent-free; temperature, $60^{\circ} \mathrm{C}$; time, $45 \mathrm{~min}$; stirring.

\begin{tabular}{ccc}
\hline Entry & Amount of Catalyst (mg) & Yields (\%) $^{\mathbf{a}}$ \\
\hline 1 & 0 & 47 \\
2 & 4 & 55 \\
3 & 10 & 58 \\
4 & 20 & 96 \\
5 & 40 & 98 \\
6 & 80 & 85
\end{tabular}

a The product was purified by liquid chromatography, and the purity control was performed by GC analysis.

The influence of temperature on the synthesis of $\mathrm{N}$-(4-methylphenyl)-2.5-dimethylpyrrol is shown in Table 4. Five experiments were performed (at 20, 40, 60, 80, and $100{ }^{\circ} \mathrm{C}$ ) using PW as a catalyst. The results indicated that optimum yields could be obtained at $60^{\circ} \mathrm{C}(98 \%$, Table 4 , entry 3$)$. A poor yield was detected when the test was performed at room temperature $\left(20^{\circ} \mathrm{C}\right)(10 \%$, Table 4 , entry 1$)$. When the temperature was increased to 80 and $100^{\circ} \mathrm{C}$, the corresponding yields were slightly reduced ( $85 \%$ and $77 \%$, respectively, Table 4 , entries 4 and 5). In these cases, unidentified secondary products were detected by GC.

Table 4. Temperature effect on product yields. Reaction conditions: 4-toluidine (1 mmol); acetonylacetone ( $1 \mathrm{mmol})$; PW catalyst ( $40 \mathrm{mg}$, ca. 1.4\%); solvent-free; time, $45 \mathrm{~min}$; stirring.

\begin{tabular}{ccc}
\hline Entry & Temperature $\left({ }^{\circ} \mathbf{C}\right)$ & Yields $(\%)^{\mathbf{a}}$ \\
\hline 1 & 20 & 10 \\
2 & 40 & 29 \\
3 & 60 & 98 \\
4 & 80 & $85^{\mathrm{b}}$ \\
5 & 100 & $77^{\mathrm{b}}$ \\
\hline
\end{tabular}

a The product was purified by liquid chromatography, and the purity control was performed by GC analysis.

${ }^{\mathrm{b}}$ In these cases, several unidentified secondary products were detected by GC.

Once the optimum temperature was determined $\left(60^{\circ} \mathrm{C}\right)$, the reaction was investigated at four different times of 30, 45, 60, and $120 \mathrm{~min}$ (Table 5). A very good yield was obtained at $30 \mathrm{~min}$ of reaction 
(72\%, Table 5, entry 1), reaching optimum yields at $45 \mathrm{~min}(89 \%$, Table 5, entry 2$)$ and without any variation at $60 \mathrm{~min}$. Finally, at $120 \mathrm{~min}$, the reaction yield decreased up to $85 \%$ (Table 5, entry 4 ) and several unidentified products were detected by GC.

Table 5. Effect of time on product yields. Reaction conditions: 4-toluidine ( $1 \mathrm{mmol})$; acetonylacetone (1 mmol); PW catalyst (40 mg, ca. $1.4 \%$ ); solvent-free; temperature, $60{ }^{\circ} \mathrm{C}$; stirring.

\begin{tabular}{ccc}
\hline Entry & Time (min) & ${\text { Yields }(\mathbf{\%})^{\mathbf{a}}}^{\mathbf{a}^{2}}$ \\
\hline 1 & 30 & 72 \\
2 & 45 & 98 \\
3 & 60 & 96 \\
4 & 120 & $85^{\mathrm{b}}$ \\
\hline
\end{tabular}

a The product was purified by liquid chromatography, and the purity control was performed by GC analysis.

${ }^{\mathrm{b}}$ In these cases, unidentified secondary products were detected by GC.

In order to study the catalyst reusability, optimum conditions $\left(60^{\circ} \mathrm{C}\right.$, under solvent-free conditions, with $40 \mathrm{mg}$ of bulk PW, and 1:1 molar ratio of reactants) were used over five consecutive tests. For this purpose, the recovered catalyst was washed with toluene $(2 \times 1 \mathrm{~mL})$ and water $(2 \times 1 \mathrm{~mL})$ and dried in vacuum at $20^{\circ} \mathrm{C}$. The results listed in Table 6 suggest no appreciable changes of the catalytic activity after three reuses. In the last two cycles, the yields decreased by over $15 \%$. Taking into account the change in color and the appearance of the recovered catalyst, catalyst deactivation may be caused by the absorption of organic species and redox processes in their metal atoms that change their structure and affect their acidity.

Table 6. Catalyst reuse. Effect on product yields (\%). Reaction conditions: 4-toluidine (1 mmol); acetonylacetone $(1 \mathrm{mmol})$; $\mathrm{PW}$ catalyst $(40 \mathrm{mg}$, ca. $1.4 \%)$; solvent-free; temperature, $60{ }^{\circ} \mathrm{C}$; time, 45 min; stirring.

\begin{tabular}{ccc}
\hline Entry & Catalyst Cycle & Yield (\%) $^{\mathbf{a}}$ \\
\hline 1 & 1 & 98 \\
2 & 2 & 95 \\
3 & 3 & $85^{\mathrm{b}}$ \\
4 & 4 & $80^{\mathrm{b}}$ \\
5 & 5 & $77^{\mathrm{b}}$ \\
\hline
\end{tabular}

a The product was purified by liquid chromatography, and the purity control was performed by GC analysis.

$\mathrm{b}$ The catalyst color changes from green to black.

Once the conditions for the reaction using the bulk catalyst (PW) were optimized, we performed additional tests using different Preyssler catalysts in bulk that were supported on alumina (Catalox SBa-90). The choice of this support is because it presents basic sites. The design of the catalyst with dual acid-base properties is very important when it is necessary to perform tandem reactions that require this property. In addition, the easy separation of supported catalysts compared to bulk catalysts is another advantage to consider.

Initially, we performed additional tests using the different synthesized catalysts. Four catalysts with different structures were tested and named $\mathrm{PW}, \mathrm{PWMo}, \mathrm{PWAl}_{2} \mathrm{O}_{3}$, and $\mathrm{PWMoAl}_{2} \mathrm{O}_{3}$ (Table 4). In a blank experiment using the $\mathrm{Al}_{2} \mathrm{O}_{3}$ support and the optimized conditions (see footnote in Table 3), a medium yield (50\%) of $\mathrm{N}$-(4-methylphenyl)-2.5-dimethylpyrrol was obtained, similar to that reached without the catalyst (Table 1, entry 1). Then, we performed two experiments using only $4 \mathrm{mg}$ of the bulk catalyst ( $\mathrm{PW}$ and $\mathrm{PWMo}$ ) in order to compare it with the supported catalysts ( $\mathrm{PWAl}_{2} \mathrm{O}_{3}$ and $\mathrm{PWMoAl}_{2} \mathrm{O}_{3}$ ) (in these cases, using $40 \mathrm{mg}$ containing $10 \%$ of active phase). In both cases, the reaction yields were $55 \%$ and $50 \%$ (Table 7 , entries 2 and 3 ). However, using the supported catalyst under the same reaction conditions, excellent yields were obtained $\left(83 \%\right.$ and $78 \%$ for $\mathrm{PWAl}_{2} \mathrm{O}_{3}$ and $\mathrm{PWMoAl}_{2} \mathrm{O}_{3}$, respectively). 
Table 7. Effect of different catalysts on product yields (\%). Reaction conditions: 4-toluidine (1 mmol); acetonylacetone $(1 \mathrm{mmol})$; catalyst ( $4 \mathrm{mg}$ of active phase); solvent-free; temperature, $60{ }^{\circ} \mathrm{C}$; time 45 min; stirring.

\begin{tabular}{ccc}
\hline Entry & Catalyst & Yields (\%) $^{\mathbf{a}}$ \\
\hline 1 & None & 47 \\
2 & $\mathrm{PW}$ & 55 \\
3 & $\mathrm{PWMo}$ & 50 \\
4 & $\mathrm{Al}_{2} \mathrm{O}_{3}$ & 50 \\
5 & $\mathrm{PWAl}_{2} \mathrm{O}_{3}$ & $83^{\mathrm{b}}(81,80,80)^{\mathrm{c}}$ \\
6 & $\mathrm{PWOAl}_{2} \mathrm{O}_{3}$ & $78^{\mathrm{b}}$ \\
\hline
\end{tabular}

\footnotetext{
a The product was purified by liquid chromatography, and the purity control was performed by GC analysis.

${ }^{\mathrm{b}}$ Catalysts with $10 \%$ of active phase. ${ }^{\mathrm{c}}$ Second, third, and fourth reuses.
}

Although the yields obtained using the bulk catalysts were excellent, the use of the catalysts supported on alumina offers three substantial advantages: (i) Easy recovery of the reaction medium. (ii) Amount of active phase (cost of the catalyst). For the supported catalysts, only $4 \mathrm{mg}$ of HPAs/HPA (active phase) was necessary in comparison to the $40 \mathrm{mg}$ used for the bulk catalysts to obtain excellent yields. (iii) Reusability of the catalyst. The recovered catalyst was reused four times with no significant loss in catalytic activity (Table 7, entry 5) compared to the reuse of the bulk catalyst (Table 6).

Several pyrroles were synthesized using different amines and acetonylacetone and PW and $\mathrm{PWAl}_{2} \mathrm{O}_{3}$ as catalysts to demonstrate the scope of this procedure (Table 8). According to the results of the optimization experiment for the reaction conditions, the reactions were carried out in the presence of catalyst ( $40 \mathrm{mg}$ of $\mathrm{PW}$ or $\mathrm{PWAl}_{2} \mathrm{O}_{3} 10 \% w / w$ active phase) under solvent-free conditions at $60{ }^{\circ} \mathrm{C}$, and the corresponding pyrrole was obtained in very good yields. The workup and catalyst recovery are very simple, and all reactions have very high selectivity toward the corresponding pyrrole. TLC and GC analyses show only traces of secondary products. After completion of the reaction (monitored by TLC, eluent; EtOAc: hexane mixtures), the product was extracted with ethyl acetate, and the catalyst was separated by centrifugation and filtration. After ethyl acetate evaporation, the crude product was easily isolated. Further purification was performed by recrystallization from ethanol or liquid column chromatography using ethyl acetate-hexane mixtures. The reaction solvent can be recovered by simple distillation and can be reused. Compound entries 1-18 are known compounds and were characterized by ${ }^{1} \mathrm{H}-\mathrm{NMR}$ and ${ }^{13} \mathrm{C}-\mathrm{NMR}$. The characterization details of all compounds are given in the Experimental methods section. It is noteworthy to mention that this is a very simple method to prepare three new compounds not reported in the literature derived from benzothiazole (Table 8 , entries 19-24).

Table 8. Synthesis of pyrrole using bulk (PW) and supported $\left(\mathrm{Al}_{2} \mathrm{O}_{3} \mathrm{PW}\right)$ catalysts. Reaction conditions: amine $(1 \mathrm{mmol})$; acetonylacetone $(1 \mathrm{mmol})$; catalyst PW $(40 \mathrm{mg})$ or $\mathrm{Al}_{2} \mathrm{O}_{3} \mathrm{PW}(40 \mathrm{mg} 10 \% \mathrm{w} / w)$; solvent-free; temperature $60^{\circ} \mathrm{C}$; stirring.

\begin{tabular}{|c|c|c|c|c|c|c|c|c|}
\hline Entry & Product $^{a}$ & $t(h)$ & $\begin{array}{c}\mathrm{Y}(\%)^{\mathrm{b}} \\
\mathrm{PW} \mathrm{Al}_{2} \mathrm{O}_{3} \mathrm{PW}\end{array}$ & $\mathrm{AE}^{\mathrm{b}}(\%)$ & $\mathbf{E F}^{\mathbf{b}}$ & PMI $^{b}$ & TON $^{b}$ & TOF $^{b}$ \\
\hline $\begin{array}{l}1 \\
2\end{array}$ & & 2 & $\begin{array}{l}85 \\
79\end{array}$ & 83 & $\begin{array}{l}0.699 \\
0.828\end{array}$ & $\begin{array}{l}1.699 \\
1.828\end{array}$ & $\begin{array}{l}3.63 \\
33.8\end{array}$ & $\begin{array}{l}1.800 \\
16.86\end{array}$ \\
\hline $\begin{array}{l}3 \\
4\end{array}$ & & 0.5 & $\begin{array}{l}98 \\
85\end{array}$ & 84 & $\begin{array}{l}0.440 \\
0.660\end{array}$ & $\begin{array}{l}1.440 \\
1.660\end{array}$ & $\begin{array}{l}4.53 \\
39.3\end{array}$ & $\begin{array}{l}9.060 \\
78.60\end{array}$ \\
\hline
\end{tabular}


Table 8. Cont.

\begin{tabular}{|c|c|c|c|c|c|c|c|c|}
\hline Entry & Product $^{a}$ & $t(h)$ & $\begin{array}{c}\mathrm{Y}(\%)^{\mathrm{b}} \\
\mathrm{PW} \mathrm{Al}_{2} \mathrm{O}_{3} \mathrm{PW}\end{array}$ & $\mathrm{AE}^{\mathrm{b}}(\%)$ & $\mathrm{EF}^{\mathbf{b}}$ & $\mathrm{PMI}^{\mathrm{b}}$ & TON $^{b}$ & TOF $^{b}$ \\
\hline $\begin{array}{l}5 \\
6\end{array}$ & & 4 & $\begin{array}{l}86 \\
83\end{array}$ & 85 & $\begin{array}{l}0.593 \\
0.650\end{array}$ & $\begin{array}{l}1.593 \\
1.650\end{array}$ & $\begin{array}{l}4.42 \\
42.6\end{array}$ & $\begin{array}{l}1.080 \\
10.68\end{array}$ \\
\hline $\begin{array}{l}7 \\
8\end{array}$ & & 18 & $\begin{array}{l}73 \\
70\end{array}$ & 86 & $\begin{array}{l}0.852 \\
0.931\end{array}$ & $\begin{array}{l}1.852 \\
1.931\end{array}$ & $\begin{array}{l}3.94 \\
37.8\end{array}$ & $\begin{array}{l}0.240 \\
2.100\end{array}$ \\
\hline $\begin{array}{c}9 \\
10\end{array}$ & & 2 & $\begin{array}{l}90 \\
82\end{array}$ & 84 & $\begin{array}{l}0.565 \\
0.718\end{array}$ & $\begin{array}{l}1.565 \\
1.718\end{array}$ & $\begin{array}{l}4.18 \\
38.1\end{array}$ & $\begin{array}{l}2.100 \\
19.08\end{array}$ \\
\hline $\begin{array}{l}11 \\
12\end{array}$ & & 3.5 & $\begin{array}{l}92 \\
81\end{array}$ & 81 & $\begin{array}{l}0.634 \\
0.856\end{array}$ & $\begin{array}{l}1.634 \\
1.856\end{array}$ & $\begin{array}{l}3.47 \\
30.6\end{array}$ & $\begin{array}{l}1.020 \\
8.760\end{array}$ \\
\hline $\begin{array}{l}13 \\
14\end{array}$ & & 3 & $\begin{array}{l}85 \\
75\end{array}$ & 86 & $\begin{array}{l}0.581 \\
0.792\end{array}$ & $\begin{array}{l}1.581 \\
1.792\end{array}$ & $\begin{array}{l}4.70 \\
41.4\end{array}$ & $\begin{array}{l}1.560 \\
13.80\end{array}$ \\
\hline $\begin{array}{l}15 \\
16\end{array}$ & & 1.5 & $\begin{array}{l}98 \\
87\end{array}$ & 86 & $\begin{array}{l}0.374 \\
0.547\end{array}$ & $\begin{array}{l}1.374 \\
1.547\end{array}$ & $\begin{array}{l}5.38 \\
47.7\end{array}$ & $\begin{array}{l}3.600 \\
31.80\end{array}$ \\
\hline $\begin{array}{l}17 \\
18\end{array}$ & & 3 & $\begin{array}{l}84 \\
76\end{array}$ & 84 & $\begin{array}{l}0.662 \\
0.837\end{array}$ & $\begin{array}{l}1.662 \\
1.837\end{array}$ & $\begin{array}{l}4.03 \\
36.5\end{array}$ & $\begin{array}{l}1.320 \\
12.18\end{array}$ \\
\hline $\begin{array}{l}19 \\
20\end{array}$ & & & $\begin{array}{l}98 \\
90\end{array}$ & 86 & $\begin{array}{l}0.361 \\
0.481\end{array}$ & $\begin{array}{l}1.361 \\
1.481\end{array}$ & $\begin{array}{l}5.59 \\
51.3\end{array}$ & $\begin{array}{l}1.860 \\
17.10\end{array}$ \\
\hline $\begin{array}{l}21 \\
22\end{array}$ & & & $\begin{array}{l}78 \\
69\end{array}$ & 88 & $\begin{array}{l}0.653 \\
0.869\end{array}$ & $\begin{array}{l}1.653 \\
1.869\end{array}$ & $\begin{array}{l}5.12 \\
45.3\end{array}$ & $\begin{array}{l}1.680 \\
15.12\end{array}$ \\
\hline $\begin{array}{l}23 \\
24\end{array}$ & & & $\begin{array}{l}50 \\
53\end{array}$ & 88 & $\begin{array}{l}1.557 \\
1.412\end{array}$ & $\begin{array}{l}2.557 \\
2.412\end{array}$ & $\begin{array}{l}3.41 \\
36.2\end{array}$ & $\begin{array}{c}1.140 \\
12.060\end{array}$ \\
\hline
\end{tabular}

a The product was purified by liquid chromatography, and the purity control was performed by GC analysis. ${ }^{b}$ Reaction yield (Y); Atom economy (AE); E-factor (EF), Process mass intensity (PMI); Turnover number (TON); Turnover frequency (TOF). 
Several greener parameters [42] were calculated for each pyrrole synthesized (Table 8 and Figure 8).

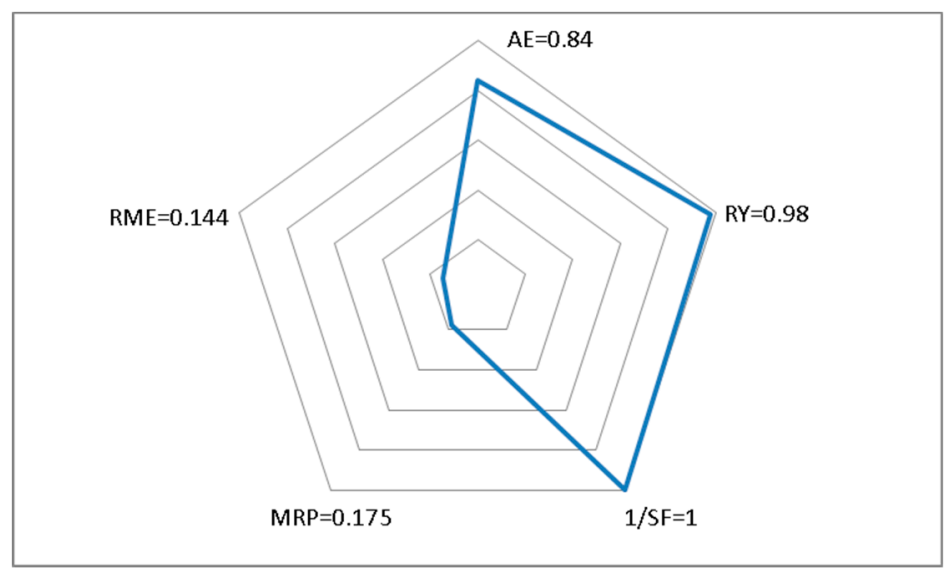

Figure 8. Radial pentagon for the tandem reaction in chromene-pyrrole synthesis.

Also, the bifunctional characteristics of these new materials allowed us to carry out a tandem synthesis of pyrroles that involves the initial formation of 2-amino-3-cyano-4-H-chromenes by a multicomponent reaction between benzaldehyde or 4-methylbenzaldehyde, malononitrile, and 2-naphthol, and their subsequent conversion to pyrrole using acetylacetone as reagent (Scheme 3), which requires catalysts with dual characteristics (acid-base).

Two new compounds with good selectivity can be obtained by this process. The two products obtained were characterized by mass spectrometry. They are unstable and decompose during their purification, and for that reason, it was impossible to determine their NMR spectra.

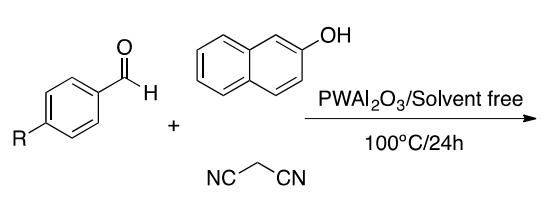

$\mathrm{R}=-\mathrm{H},-\mathrm{CH}_{3}$

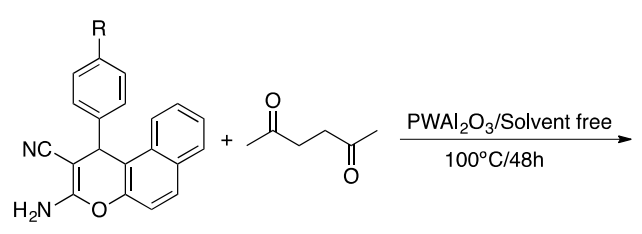

$\mathrm{R}=-\mathrm{H}$, Conv. $63 \%$, select. $100 \%$ $\mathrm{R}=-\mathrm{CH}_{3}$, Conv. $60 \%$, select. $100 \%$

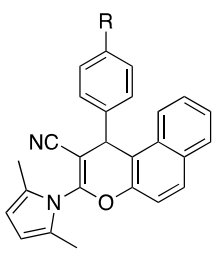

$\mathrm{R}=-\mathrm{H}$, Conv. $20 \%$, select. $79 \%$ $\mathrm{R}=-\mathrm{CH}_{3}$, Conv. $22 \%$, select. $78 \%$

Scheme 3. Multicomponent synthesis of chromene-pyrroles.

Based on the literature consulted, we propose a plausible mechanism for the synthesis of these chromene-pyrroles comprising two steps (Scheme 4): a first step in which the multicomponent synthesis of chromene takes place promoted by basic sites [43], and a second step through the mechanism of the Paal-Knorr reaction in which pyrroles are finally obtained via acid catalysis [44].

To determine the importance of the dual role of the catalysts employed in this work, chromene synthesis was carried out using only PW or PWMo, obtaining an unclear reaction with a majority formation of secondary products, making chromene isolation unfeasible. On the other hand, a clean reaction with good products yield was achieved when this same reaction was carried out using alumina as a catalyst.

The use of alumina as a catalyst in the second step of the process (Paal-Knorr reaction) was also proved, and in this case, no pyrrole formation was observed. In summary, the basic catalyst is useful for the first part of the reaction but not for the second step (Paal-Knorr reaction), and the acid catalyst is not useful for the first step but is necessary for the Paal-Knorr reaction. 


\section{Step 1}
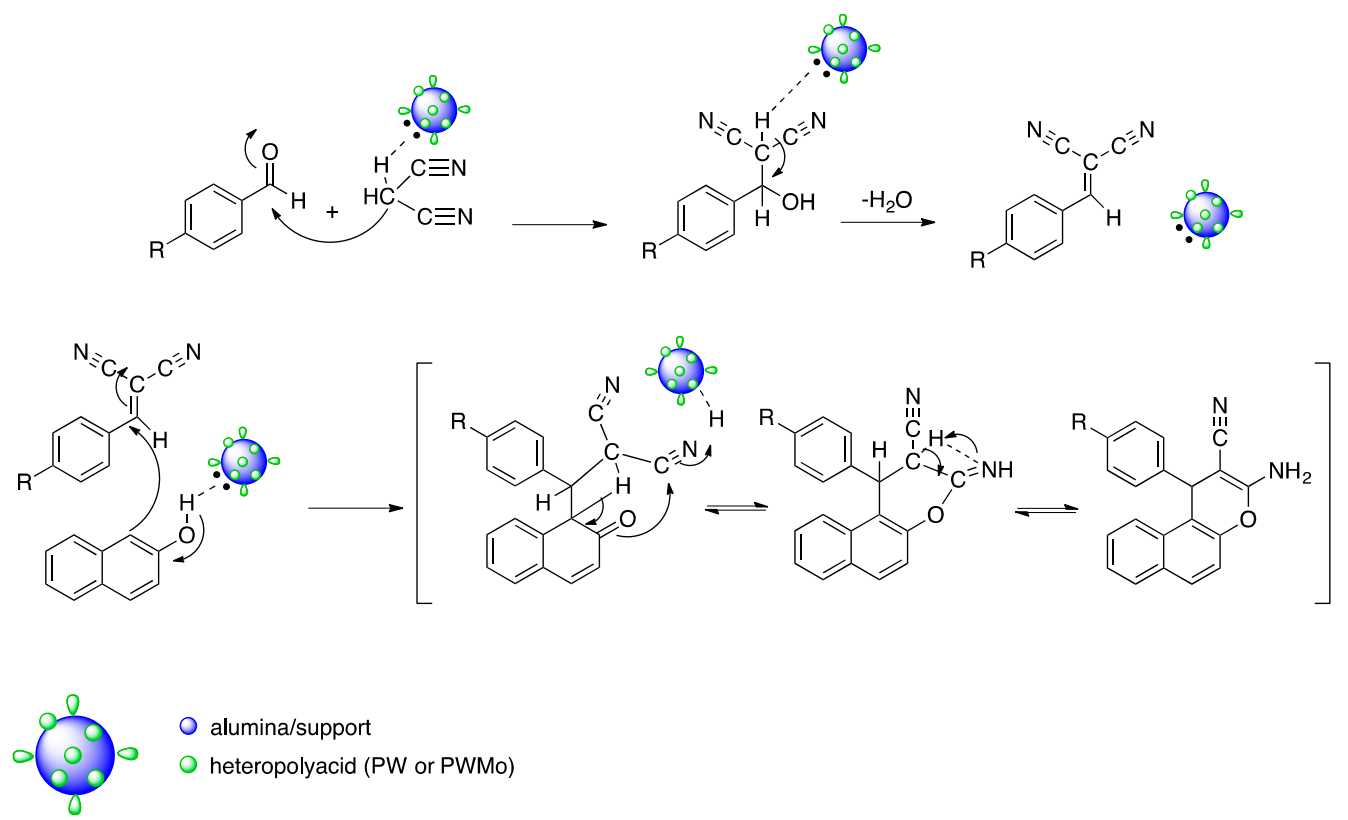

Step 2
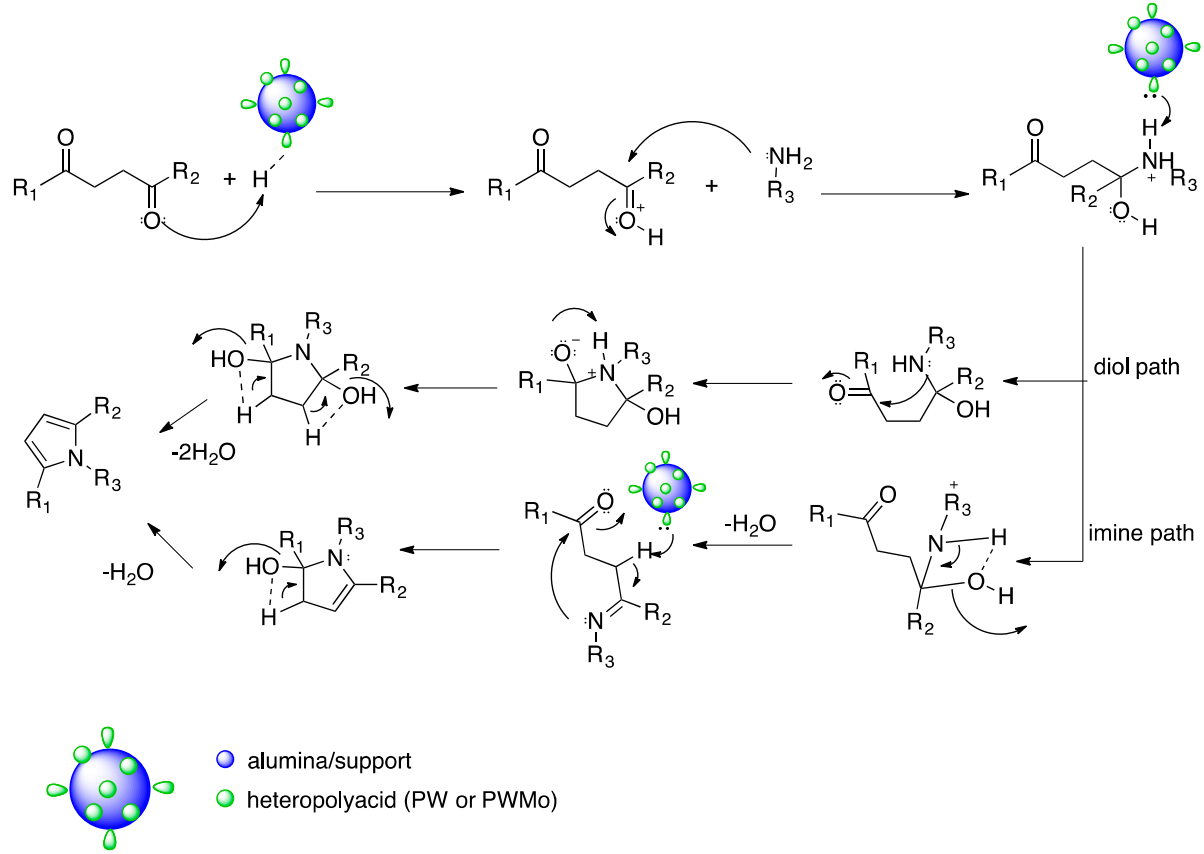

Scheme 4. Plausible mechanism of chromene-pyrrole synthesis.

To confirm the formation of these compounds, an additional experiment was performed. The unstable crude product obtained in 3.4.4 (using benzaldehyde as a substrate) was hydrolyzed in the presence of $1 \mathrm{M} \mathrm{HCl}$ to obtain the chromene-pyrrole carboxylic acid derivative (Scheme 5). The product was identified by ${ }^{1} \mathrm{H},{ }^{13} \mathrm{C}$ NMR, and FT-IR. 


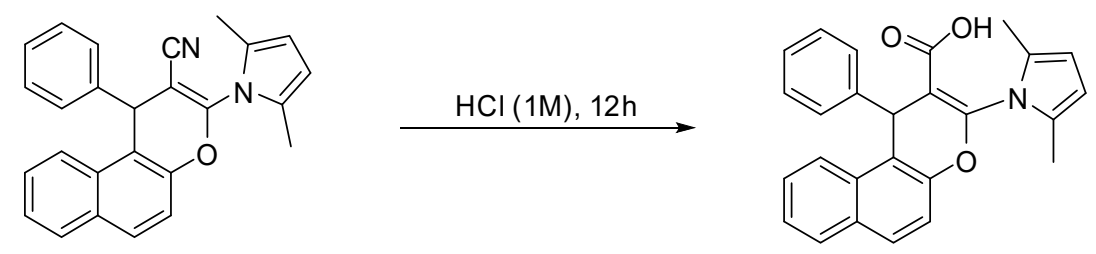

Scheme 5. Synthesis of chromene-pyrrole carboxylic acid derivatives.

\section{Materials and Methods}

\subsection{General}

Chemicals were purchased from Aldrich (Buenos Aires, Argentina) and used without further purification. 2-Amino-3-cyano-4-H-chromenes used as standards were prepared essentially following a method reported in the literature [45]. TLC was done on aluminum sheets precoated with silica gel and fluorescence indicator. The GC analysis was performed in a Shimadzu GC-2014 (La Plata, Buenos Aires, Argentina) with an FID detector using a calibration curve method. The solid products were purified by recrystallization from ether-ethyl acetate (1:2), and the melting points were determined using Bioamerican Bs 448 apparatus and were uncorrected. All compounds were identified by ${ }^{1} \mathrm{H}$ and ${ }^{13} \mathrm{C}-\mathrm{NMR}, \mathrm{IR}$, and MS data with those reported. The ${ }^{1} \mathrm{H}$ NMR spectra were recorded at $400 \mathrm{MHz}$ and ${ }^{13} \mathrm{C}$ NMR spectra at $100 \mathrm{MHz}$ in a Bruker Advance 400 spectrometer, in $\mathrm{CDCl}_{3}$ and $d_{6}$-DMSO with TMS as an internal reference. The chemical shifts were reported as $\delta$ values (ppm) relative to TMS. IR spectra were recorded in a Bruker IFS 66 (Tunja, Boyacá, Colombia). Ultra-high-performance liquid chromatography coupled with tandem mass spectrometry (UHPLC-MS/MS) analysis was performed using an ACQUITY UPLC system coupled to a Quattro Premier XE tandem quadrupole mass spectrometer (Balcarce, Buenos Aires, Argentina).

\subsection{Catalyst Synthesis}

\subsubsection{Bulk Preyssler Heteropolyacid Synthesis}

$\left(\mathrm{H}_{14}\left[\mathrm{NaP}_{5} \mathrm{~W}_{30} \mathrm{O}_{110}\right]\right)(\mathrm{PW})$ was prepared by a hydrothermal synthesis method, essentially following a procedure described in the literature [46,47]. First, $30 \mathrm{~g}$ of $\mathrm{Na}_{2} \mathrm{WO}_{4} \cdot 2 \mathrm{H}_{2} \mathrm{O}(0.13 \mathrm{~mol})$ was dissolved in $20 \mathrm{~mL}$ of hot distilled water. Then, $27 \mathrm{~mL}$ of $\mathrm{H}_{3} \mathrm{PO}_{4}, 85 \%(0.02 \mathrm{~mol})$ was added dropwise to the solution, and the resulting mixture was refluxed for $24 \mathrm{~h}$. Subsequently, $1 \mathrm{~mL}$ of concentrated nitric acid (65\%) was added to the mixture with constant stirring followed by $10 \mathrm{~g}$ of pure $\mathrm{KCl}(0.13 \mathrm{~mol})$. The suspension obtained was centrifuged for $15 \mathrm{~min}$, and the resulting solid was dissolved in $50 \mathrm{~mL}$ of hot distilled water and kept under cooling ( $4{ }^{\circ} \mathrm{C}$ approx.) for $24 \mathrm{~h}$. The precipitate obtained $\left(\mathrm{K}_{14}\left[\mathrm{NaP}_{5} \mathrm{~W}_{30} \mathrm{O}_{110}\right]\right)$ was filtered and dried under vacuum at room temperature. A $10 \%$ solution of the potassium salt obtained was eluted through a previously activated Dowex $^{\circledR} 50 \mathrm{~W}$ X8 hydrogen bed. The exchanged solution was then brought to dryness by forced evaporation under an air column to obtain the product $\mathrm{H}_{14}\left[\mathrm{NaP}_{5} \mathrm{~W}_{30} \mathrm{O}_{110}\right]$ (HPA). The Preyssler heteropolyacid with molybdenum addenda atom $\mathrm{H}_{14}\left[\mathrm{NaP}_{5} \mathrm{~W}_{29} \mathrm{MoO}_{110}\right]$ (PWMo) was similarly synthesized using a $0.07 / 8.3 \mathrm{mmol}$ ratio following the same steps as for PW.

\subsubsection{Alumina-Supported Preyssler Catalyst Synthesis}

The alumina support CATALOX SBa- $90^{\circledR}$ (SASOL) was used as received without any pretreatment. In a typical experiment, a solution of $0.3 \mathrm{~g}$ of PW (or PWMo) in $6 \mathrm{~mL}$ of water was added to $3 \mathrm{~g}$ of support. The mixture was stirred at $1000 \mathrm{rpm}$ for $3 \mathrm{~h}$ at room temperature. The resulting slurry was dried under vacuum at room temperature for $24 \mathrm{~h}$. The two alumina-supported catalysts were named $\mathrm{PWAl}_{2} \mathrm{O}_{3}$ and $\mathrm{PWMOAl}_{2} \mathrm{O}_{3}$. 


\subsection{Catalyst Characterization}

The textural properties of the solids were determined from the $\mathrm{N}_{2}$ adsorption-desorption isotherms at liquid nitrogen temperature using Micrometrics ASAP 2020 equipment. FT-IR signals characteristic of the heteropolyacid in the $400-4000 \mathrm{~cm}^{-1}$ wavenumber range were obtained using $\mathrm{KBr}$ pellets in Nicolet iS50 equipment. The nature of acid sites was obtained by pyridine ( $p y)$ adsorption followed by FT-IR using an in situ diffuse reflectance cell (Praying Mantis, Harrick). In the same manner, the acid strength was determined by potentiometric titration using $n$-butylamine $(0.025 \mathrm{~N})$ solution at a flow rate of $0.05 \mathrm{~mL} / \mathrm{min}$ in 794 Basic Titrino Metrohm equipment using a double junction electrode. The protocols of these techniques were described previously in reference [26].

\subsection{Catalytic Synthesis of Pyrrole Derivatives}

\subsubsection{General Procedure for the Synthesis of Pyrrole Derivatives}

The reaction was carried out using $1 \mathrm{mmol}$ of amine and $1 \mathrm{mmol}$ of acetylacetone with $40 \mathrm{mg}$ of catalyst at $60{ }^{\circ} \mathrm{C}$ for the time indicated in Table 6 (to the end point of the reaction, checked by TLC). The pyrrole derivatives were extracted with ethyl acetate $(3 \times 5 \mathrm{~mL})$ and the catalyst was separated by centrifugation and filtration. The product was purified by column chromatography (hexane/ethyl acetate mixtures) and recrystallized from ethanol. The compounds were identified by ${ }^{1} \mathrm{H}$ and ${ }^{13} \mathrm{C}$ NMR, and IR data with those reported.

\subsubsection{Melting Point, ${ }^{1} \mathrm{H}-\mathrm{NMR}$, and ${ }^{13} \mathrm{C}-\mathrm{NMR}$ of Synthesized Compounds}

2,5-Dimethyl-1-(p-tolyl)-1H-pyrrole: Brown solid, m.p.: $45-47^{\circ} \mathrm{C} ;{ }^{1} \mathrm{H} \mathrm{NMR}\left(400 \mathrm{MHz}, \mathrm{CDCl}_{3}\right), \delta$ (ppm) 7.30-7.28 (dd, $J=7.72, J=0.72 \mathrm{~Hz}, 2 \mathrm{H}), 7.14-7.12(\mathrm{~d}, J=8.34 \mathrm{~Hz}, 2 \mathrm{H}), 5.93(\mathrm{~s}, 2 \mathrm{H}), 2.40(\mathrm{~s}, 3 \mathrm{H}), 2.01(\mathrm{~s}$, $6 \mathrm{H}) ;{ }^{13} \mathrm{C}$ NMR $\left(100 \mathrm{MHz}, \mathrm{CDCl}_{3}\right), \delta$ (ppm) 137.44, 136.35, 129.67, 128.85, 127.97, 105.42, 21.15, 13.00 .

2,5-Dimethyl-1-phenyl-1H-pyrrole: Dark brown oil; ${ }^{1} \mathrm{H}$ NMR $\left(400 \mathrm{MHz}, \mathrm{CDCl}_{3}\right), \delta(\mathrm{ppm}) 7.51-7.41$ (m, $3 \mathrm{H}), 7.25(\mathrm{~d}, J=6.0 \mathrm{~Hz}, 1 \mathrm{H}), 5.94(\mathrm{~s}, 2 \mathrm{H}), 2.07(\mathrm{~s}, 6 \mathrm{H}) ;{ }^{13} \mathrm{C} \mathrm{NMR}\left(100 \mathrm{MHz}, \mathrm{CDCl}_{3}\right), \delta(\mathrm{ppm}) 139.74$, $129.07,129.0,127.58,127.51,127.6,127.49,109.6,109.23$.

2,5-Dimethyl-1-(4-chlorophenyl)-1H-pyrrole: Brown reddish solid, m.p.: $56-57{ }^{\circ} \mathrm{C} ;{ }^{1} \mathrm{H}$ NMR $(400 \mathrm{MHz}$, $\left.\mathrm{CDCl}_{3}\right), \delta(\mathrm{ppm}) 7.48-7.47(\mathrm{~m}, 2 \mathrm{H}), 7.195(\mathrm{~d}, J=8.60 \mathrm{~Hz}, 2 \mathrm{H}), 5.95(\mathrm{~s}, 2 \mathrm{H}), 2.07(\mathrm{~s}, 6 \mathrm{H}) ;{ }^{13} \mathrm{C} \mathrm{NMR}$ $\left(100 \mathrm{MHz}, \mathrm{CDCl}_{3}\right), \delta$ (ppm) 133.54, 129.52, 129.33, 128.74, 106.06, 12.99 .

2,5-Dimethyl-1-(4-nitrophenyl)-1H-pyrrole: Reddish solid, m.p.: $148-149{ }^{\circ} \mathrm{C} ;{ }^{1} \mathrm{H}$ NMR $(400 \mathrm{MHz}$, $\left.\mathrm{CDCl}_{3}\right), \delta(\mathrm{ppm}) 8.374(\mathrm{~d}, J=8.98,1 \mathrm{H}), 7.415(\mathrm{~d}, J=8.99 \mathrm{~Hz}, 2 \mathrm{H}), 7.287(\mathrm{~s}, 1 \mathrm{H}), 5.98(\mathrm{~s}, 2 \mathrm{H}), 2.09(\mathrm{~s}, 6 \mathrm{H})$; ${ }^{13} \mathrm{C} \mathrm{NMR}\left(100 \mathrm{MHz}, \mathrm{CDCl}_{3}\right), \delta$ (ppm) 144.75, 128.79, 128.56, 124.55, 107.36, 77.32, 77.00, 76.65, 13.13.

2,5-Dimethyl-1-(4-chlorobenzyl)-1H-pyrrole: Yellow oil; ${ }^{1} \mathrm{H}$ NMR $\left(400 \mathrm{MHz}, \mathrm{CDCl}_{3}\right), \delta$ (ppm) 7.30 $(\mathrm{d}, J=8.51,2 \mathrm{H}), 6.85(\mathrm{~d}, J=8.25 \mathrm{~Hz}, 2 \mathrm{H}), 5.94(\mathrm{~s}, 2 \mathrm{H}), 5.07(\mathrm{~s}, 2 \mathrm{H}), 2.17(\mathrm{~s}, 6 \mathrm{H}) ;{ }^{13} \mathrm{C} \mathrm{NMR}(100 \mathrm{MHz}$, $\left.\mathrm{CDCl}_{3}\right), \delta$ (ppm) 135.4, 131.3, 128.7, 128.56, 128.45, 128.40, 127.80, 105.7, 13.10 .

2-(2,5-Dimethyl-1H-pyrrol-1-yl) aniline: Black needles, m.p.: 70-71 ${ }^{\circ} \mathrm{C} ;{ }^{1} \mathrm{H}$ NMR $\left(400 \mathrm{MHz}, \mathrm{CDCl}_{3}\right), \delta$ (ppm) 7.29-7.25 (m, 1H), $7.05(\mathrm{~d}, J=9.0 \mathrm{~Hz}, 1 \mathrm{H}), 6.85-6.70(\mathrm{~m}, 2 \mathrm{H}), 5.97(\mathrm{~s}, 2 \mathrm{H}), 3.39(\mathrm{~s}, \mathrm{br}, 2 \mathrm{H}), 2.10(\mathrm{~s}$, $6 \mathrm{H}) ;{ }^{13} \mathrm{C}$ NMR $\left(100 \mathrm{MHz}, \mathrm{CDCl}_{3}\right), \delta$ (ppm) 147.33, 130.85, 130.85, 128.34, 124.63, 119.81, 118.79, 109.38 .

2,5-Dimethyl-1-butyl-1H-pyrrole: Pale yellow oil; ${ }^{1} \mathrm{H}$ NMR (400 MHz, $\left.\mathrm{CDCl}_{3}\right), \delta$ (ppm) 5.80 (s, 2H), $3.76(\mathrm{t}, \mathrm{J}=7.6 \mathrm{~Hz}, 2 \mathrm{H}), 2.26(\mathrm{~s}, 6 \mathrm{H}), 1.62$ (quintet, $J=7.6 \mathrm{~Hz}, 2 \mathrm{H}), 1.40$ (sextet, $J=7.6 \mathrm{~Hz}, 2 \mathrm{H}), 0.98(\mathrm{t}$, $J=7.6 \mathrm{~Hz}, 3 \mathrm{H}) ;{ }^{13} \mathrm{C}$ NMR $\left(100 \mathrm{MHz}, \mathrm{CDCl}_{3}\right), \delta$ (ppm) 127.28, 104.90, 43.39, 33.14, 20.17, 14.17, 12.45 .

2,5-Dimethyl-1-(naphthalen-1-yl)-1H-pyrrole: White needles, m.p.: $117-118{ }^{\circ} \mathrm{C},{ }^{1} \mathrm{H}$ NMR $(400 \mathrm{MHz}$, $\left.\mathrm{CDCl}_{3}\right), \delta(\mathrm{ppm}) 7.95(\mathrm{~d}, J=8.44 \mathrm{~Hz}, 2 \mathrm{H}), 7.60-7.43(\mathrm{~m}, 4 \mathrm{H}), 7.16(\mathrm{~d}, J=8.35 \mathrm{~Hz}, 1 \mathrm{H}), 6.03(\mathrm{~s}, 2 \mathrm{H})$, $1.92(\mathrm{~s}, 6 \mathrm{H}) ;{ }^{13} \mathrm{C}$ NMR $\left(100 \mathrm{MHz}, \mathrm{CDCl}_{3}\right), \delta$ (ppm) 135.76, 134.19, 131.90, 129.86, 128.52, 128.03, 127.18, $126.50,126.23,125.37,123.31,105.39,12.55$. 
2,5-Dimethyl-1-(benzothiazol-2-yl)-1H-pyrrole: Dark brown oil; ${ }^{1} \mathrm{H}$ NMR $\left(400 \mathrm{MHz}, \mathrm{CDCl}_{3}\right), \delta$ (ppm) $8.08(\mathrm{dd}, J=4.8 \mathrm{~Hz}, 2 \mathrm{H}), 7.91(\mathrm{dt}, J=8.0, J=0.4 \mathrm{~Hz}, 1 \mathrm{H}), 7.56(\mathrm{dt}, J=7.6, J=1.6 \mathrm{~Hz}, 1 \mathrm{H}), 7.47(\mathrm{td}, J=7.8$, $J=1.4 \mathrm{~Hz}, 1 \mathrm{H}), 5.97(\mathrm{~s}, 2 \mathrm{H}), 2.35(\mathrm{~s}, 6 \mathrm{H}) ;{ }^{13} \mathrm{C} \mathrm{NMR}\left(100 \mathrm{MHz}, \mathrm{CDCl}_{3}\right), \delta(\mathrm{ppm}) 158.61,150.38,135.10$, $130.04,126.51,125.51,123.43,121.42,108.63,13.58$.

2-(2,5-Dimethyl-1H-pyrrol-1-yl)-6-nitrobenzo[d]thiazole: Brown solid; m.p.: $125-128{ }^{\circ} \mathrm{C} ;{ }^{1} \mathrm{H}$ NMR $\left(400 \mathrm{MHz}, \mathrm{CDCl}_{3}\right), \delta(\mathrm{ppm}) 8.82-8.81(\mathrm{~s}, 1 \mathrm{H}), 8.41-8.39(\mathrm{~d}, J=7.5 \mathrm{~Hz}, 1 \mathrm{H}), 8.11-8.09(\mathrm{~d}, J=7.45 \mathrm{~Hz}, 1 \mathrm{H})$, $6.01(\mathrm{~s}, 2 \mathrm{H}), 2.45(\mathrm{~s}, 6 \mathrm{H}) ;{ }^{13} \mathrm{C} \mathrm{NMR}\left(100 \mathrm{MHz}, \mathrm{CDCl}_{3}\right), \delta$ (ppm) 162.62, 153.82, 144.31, 133.96, 129.85, $122.65,121.47,117.34,109.75,13.83$.

6-Chloro-2-(2,5-dimethyl-1H-pyrrol-1-yl) benzo[d]thiazole: Dark brown oil; ${ }^{1} \mathrm{H}$ NMR $(400 \mathrm{MHz}$, $\left.\mathrm{CDCl}_{3}\right), \delta(\mathrm{ppm}) 7.97-7.96(\mathrm{~d}, J=1.5 \mathrm{~Hz}, 1 \mathrm{H}), 7.87-7.86(\mathrm{~d}, J=7.5, J=1.4 \mathrm{~Hz}, 1 \mathrm{H}), 7.52-7.50(\mathrm{~d}, J=7.6$, $J=1.6 \mathrm{~Hz}, 1 \mathrm{H}), 5.98(\mathrm{~s}, 2 \mathrm{H}), 2.36(\mathrm{~s}, 6 \mathrm{H}) ;{ }^{13} \mathrm{C} \mathrm{NMR}\left(100 \mathrm{MHz}, \mathrm{CDCl}_{3}\right), \delta$ (ppm) 158.84, 148.86, 136.04, $131.35,130.05,127.32,124.14,120.99,109.00,13.69$.

\subsubsection{Catalyst Reuse}

The reuse of the catalysts was studied during five consecutive experiments under the same reaction conditions. The catalyst was separated, washed with ethyl acetate $(3 \times 3 \mathrm{~mL})$, dried, and then reused.

\subsubsection{Specific Process for the Multicomponent Synthesis of Chromene-Pyrrole Derivative}

A mixture of benzaldehyde or 4-methylbenzaldehyde (1 mmol), naphthol (1 mmol), malononitrile ( $1 \mathrm{mmol})$, and the PW catalyst $(40 \mathrm{mg})$ was stirred at $100{ }^{\circ} \mathrm{C}$ for $24 \mathrm{~h}$. Then, acetylacetone $(1 \mathrm{mmol})$ was added, and the stirring was continued for a further $24 \mathrm{~h}$ at $100^{\circ} \mathrm{C}$ (to the end point of the reaction, checked by TLC). On cooling, the reaction mixture was extracted with ethyl acetate $(3 \times 4 \mathrm{~mL})$, and the catalyst was separated by centrifugation and filtration to give the crude product. The conversion and selectivity were determined by GC, and the reaction products were characterized by mass spectrometry.

\subsubsection{Mass Spectrum of Synthetized Chromene-Pyrrole Derivatives}

3-(2,5-Dimethyl-1H-pyrrol-1-yl)-1-phenyl-1H-benzo[f]chromene-2-carbonitrile: MS ( $\mathrm{m} / \mathrm{z}, \%) 377.0$ ([M - H] $\left.]^{+}, 25\right), 376.0$ (100), 348.0 (100), 331.0 (20), 298.8 (70), 291.1 (30), 278.9 (30), 126.7 (20), 105.0 (50).

3-(2,5-Dimethyl-1H-pyrrol-1-yl)-1-(p-tolyl)-1H-benzo[f]chromene-2-carbonitrile: MS $(\mathrm{m} / \mathrm{z}, \%) 391$ ([M $\left.-\mathrm{H}]^{+}, 20\right), 390.9$ (100), 359.1 (40), 331.0 (40), 312.9 (80), 170.6 (20), 126.9 (30).

3.4.6. Specific Procedure for the Multicomponent Synthesis of Chromene-Pyrrole Carboxylic Acid Derivative

The unstable crude product obtained in Section 3.4.4 was hydrolyzed in the presence of $1 \mathrm{M}$ $\mathrm{HCl}(20 \mathrm{~mL})$ under reflux for $12 \mathrm{~h}$ to obtain the chromene-pyrrole carboxylic acid derivative as the major reaction product (Scheme 3) The product was purified by column chromatography (petroleum ether/ethyl acetate mixtures) and recrystallized from ethanol to give one stable product that was characterized by ${ }^{1} \mathrm{H}-\mathrm{NMR},{ }^{13} \mathrm{C}$ NMR, and FT-IR.

3.4.7. ${ }^{1} \mathrm{H}-\mathrm{NMR},{ }^{13} \mathrm{C}-\mathrm{NMR}$, and IR Spectra of Synthesized Chromene-Pyrrole Carboxylic Acid Derivative

3-(2,5-Dimethyl-1H-pyrrol-1-yl)-1-phenyl-1H-benzo[f]chromene-2-carboxylic acid: ${ }^{1} \mathrm{H}$ NMR $\left(400 \mathrm{MHz}, \mathrm{CDCl}_{3}\right), \delta(\mathrm{ppm}) 11.04(\mathrm{~s}, 1 \mathrm{H}), 7.89(\mathrm{~m}, 2 \mathrm{H}), 7.54(\mathrm{~m}, 1 \mathrm{H}), 7.49(\mathrm{~m}, 1 \mathrm{H}), 7.42(\mathrm{~m}, 1 \mathrm{H})$, $7.28(\mathrm{~m}, 1 \mathrm{H}), 7.24(\mathrm{~m}, 1 \mathrm{H}), 5.99-5.98(\mathrm{~d}, 1 \mathrm{H}) ;{ }^{13} \mathrm{C} \mathrm{NMR}\left(100 \mathrm{MHz}, \mathrm{CDCl}_{3}\right), \delta(\mathrm{ppm}) 167.76,149.89$, $148.68,138.13,131.46,130.88,128.21,127.89,127.68,127.28,127.24,125.78,125.72,123.75,123.55,117.63$, 104.86, 37.53-36.69, 11.27. FT-IR (KBr): $v\left(\mathrm{~cm}^{-1}\right)$ 3319, 3107, 3067, 2926, 1758, 1615, 1590, 1520, 1433, $1403,1277,1044,1015$. 


\section{Conclusions}

The synthesis and characterization of two new materials based on a Preyssler catalyst supported on mesoporous alumina (Catalox SBa-90) was reported with the purpose of recovering the catalyst more easily after the reaction and providing dual functionality (acid-base) to carry out tandem reactions for the synthesis of new pyrroles. The synthesis of the catalyst by impregnation techniques in water was satisfactory, and the materials maintained their structure intact after the synthesis. The samples were characterized by FT-IR and textural properties $\left(S_{B E T}\right)$, and the acid-base characteristics of the materials were determined by potentiometric titration with $n$-butylamine and in situ FT-IR analysis of pyridine absorption and desorption. Twelve pyrroles (three containing the 2-aminobenzothiazole substructure are new) were synthesized using bulk and supported catalysts under solvent-free conditions. This methodology using both catalyst types requires a short reaction time (approx. $0.5-3 \mathrm{~h}$ ) and a temperature of $60{ }^{\circ} \mathrm{C}\left(100{ }^{\circ} \mathrm{C}\right.$ in the case of pyrroles containing the 2-aminobenzothiazole substructure) to obtain good to excellent yields. The yields obtained for both bulk and supported catalysts are comparable, although the amount of active phase used in the latter is 10 times lower ( 40 vs. $4 \mathrm{mg}$ of active phase), which contributes to obtaining a lower cost catalyst. The parameters of sustainability determined for the reaction and the recyclability show that the process is of low environmental impact when compared to existing processes. Also, only the alumina-supported material was effective to prepare more complex pyrrole derivatives, through a tandem one-pot process that involves the formation of 2-amino-3-cyano $4-H$-chromenes by a multicomponent reaction and their subsequent conversion to a pyrrole derivative. This indicates the need for a catalyst with dual acid-base properties to improve this procedure. In sum, materials that can be considered as sustainable catalysts were prepared, and they were used in a Paal-Knorr synthesis of pyrroles under solvent-free conditions with good results. The use of these catalysts in the green synthesis of other heterocycles through a multicomponent reaction and the biomass valorization are in progress in our laboratory.

Supplementary Materials: The following are available online http:/ /www.mdpi.com/2073-4344/8/10/419/s1. ${ }^{1} \mathrm{H},{ }^{13} \mathrm{C}$ RMN of benzothiazole and chromene pyrrole derivatives, and green metrics details.

Author Contributions: Conceptualization and Methodology, O.P.-Z., A.S. and G.P.R.; methods validation, O.P.-Z.; Mass determinations, E.D.G.; Writing-Original Draft Preparation, O.P.-Z.; Writing-Review \& Editing, O.P.-Z., A.S. and G.P.R.; Supervision, G.P.R., A.S., J.M., H.R. and R.L.; Project Administration, G.P.R.; Funding Acquisition, G.P.R. and A.S.

Funding: This work was supported by CONICET (PIP 003), ANPCyT (PICT 2013-0409), UNLP, and ERANET-LAC-1. The publication has been prepared with support from RUDN University Program 5-100.

Acknowledgments: A.S. and G.P.R. are members of CONICET. This work is a collaboration with the Laboratorio de Catálisis of the Universidad Pedagógica y Tecnológica de Colombia (UPTC). Finally, we thank the SASOL company that kindly provided the alumina sample used in this study. All authors read and approved the manuscript.

Conflicts of Interest: The authors declare no conflict of interest.

\section{References}

1. Anastas, P.T.; Warner, J.C. Green Chemistry: Theory and Practice; Oxford University Press: Oxford, UK, 1998.

2. Ji, S.-J.; Wang, S.-Y.; Zhang, Y.; Loh, T.-P. Facile synthesis of bis(indolyl)methanes using catalytic amount of iodine at room temperature under solvent-free conditions. Tetrahedron 2004, 60, 2051-2055. [CrossRef]

3. Khurana, J.M.; Kumar, S. Tetrabutylammonium bromide (TBAB): A neutral and efficient catalyst for the synthesis of biscoumarin and 3,4-dihydropyrano[c]chromene derivatives in water and solvent-free conditions. Tetrahedron Lett. 2009, 50, 4125-4127. [CrossRef]

4. Ko, S.; Yao, C.F. Heterogeneous catalyst: Amberlyst-15 catalyzes the synthesis of 14-substituted-14Hdibenzo[a,j]xanthenes under solvent-free conditions. Tetrahedron Lett. 2006, 47, 8827-8829. [CrossRef] 
5. Bose, D.S.; Fatima, L.; Mereyala, H.B. Green Chemistry Approaches to the Synthesis of 5-Alkoxycarbonyl4-aryl-3,4-dihydropyrimidin-2(1H)-ones by a Three-Component Coupling of One-Pot Condensation Reaction: Comparison of Ethanol, Water, and Solvent-free Conditions. J. Org. Chem. 2003, 68, 587-590. [CrossRef] [PubMed]

6. Li, C.J.; Wei, C. Highly efficient Grignard-type imine additions via C-H activation in water and under solvent-free conditions. Chem. Commun. 2002, 3, 268-269. [CrossRef]

7. Enache, D.I.; Edwards, J.K.; Landon, P.; Solsona-Espriu, B.; Carley, A.F.; Herzing, A.A.; Watanabe, M.; Kiely, C.J.; Knight, D.W.; Hutchings, G.J. Solvent-Free Oxidation of Primary Alcohols to Aldehydes Using $\mathrm{Au}-\mathrm{Pd} / \mathrm{TiO}_{2}$ Catalysts. Science 2006, 311, 362-365. [CrossRef] [PubMed]

8. Chen, J.; Wu, H.; Zheng, Z.; Jin, C.; Zhang, X.; Su, W. An approach to the Paal-Knorr pyrroles synthesis catalyzed by $\mathrm{Sc}(\mathrm{OTf})_{3}$ under solvent-free conditions. Tetrahedron Lett. 2006, 47, 5383-5387. [CrossRef]

9. Harreus, A.L. Pyrrole. In Ullman's Encyclopedia of Industrial Chemistry, 7th ed.; Elvers, B., Ed.; Wiley-VCH Verlag GmbH \& Co. KGaA: Weinheim, Germany, 2000; Volume 30, pp. 615-617.

10. Mal, D.; Shome, B.; Dinda, B.K. Heterocycles in Natural Product Synthesis; Majumdar, K.C., Chattopadhyay, S.K., Eds.; Wiley-VCH Verlag GmbH \& Co. KGaA: Weinheim, Germany, 2011; pp. 187-215.

11. Teixeira, C.; Barbault, F.; Rebehmed, J.; Liu, K.; Xie, L.; Lu, H.; Jiang, S.; Fan, B.T.; Maurel, F. Molecular modeling studies of N-substituted pyrrole derivatives-Potential HIV-1 gp41 inhibitors. Bioorg. Med. Chem. 2008, 16, 3039-3048. [CrossRef] [PubMed]

12. Bhardwaj, V.; Gumber, D.; Abbot, V.; Dhiman, S.; Sharma, P. Pyrrole: A resourceful small molecule in key medicinal hetero-aromatics. RSC Adv. 2015, 5, 15233-15266. [CrossRef]

13. Wurz, R.P.; Charette, A.B. Doubly activated cyclopropanes as synthetic precursors for the preparation of 4-nitro- and 4-cyano-dihydropyrroles and pyrroles. Org. Lett. 2005, 7, 2313-2316. [CrossRef] [PubMed]

14. Li, J.J. Heterocyclic Chemistry in Drug Discovery; Wiley-VCH Verlag GmbH \& Co. KGaA: Weinheim, Germany, 2013; pp. 18-51.

15. Wang, Z. Comprehensive Organic Name Reactions and Reagents; Wiley-VCH Verlag GmbH \& Co. KGaA: Weinheim, Germany, 2010; pp. 1-4.

16. Brummond, K.M.; Curran, D.P.; Mitasev, B.; Fischer, S. Heterocyclic $\alpha$-alkylidene cyclopentenones obtained via a Pauson-Khand reaction of amino acid derived allenynes. A scope and limitation study directed toward the preparation of a tricyclic pyrrole library. J. Org. Chem. 2005, 70, 1745-1753. [CrossRef] [PubMed]

17. Vekariya, R.H.; Patel, H.D. Sulfonated polyethylene glycol (PEG-OSO$\left.{ }_{3} \mathrm{H}\right)$ as a polymer supported biodegradable and recyclable catalyst in green organic synthesis: Recent advances. RSC Adv. 2015, 5, 49006-49030. [CrossRef]

18. Wang, B.; Gu, Y.; Luo, C.; Yang, T.; Yang, L.; Suo, J. Pyrrole synthesis in ionic liquids by Paal-Knorr condensation under mild conditions. Tetrahedron Lett. 2004, 45, 3417-3419. [CrossRef]

19. Sharma, A.; Piplani, P. Microwave-activated Synthesis of Pyrroles: A Short Review. J. Heterocycl. Chem. 2017, 54, 27-34. [CrossRef]

20. Zhang, Z.H.; Li, J.J.; Li, T.S. Ultrasound-assisted synthesis of pyrroles catalyzed by zirconium chloride under solvent-free conditions. Ultrason. Sonochem. 2008, 15, 673-676. [CrossRef] [PubMed]

21. Romanelli, G.P.; Autino, J.C. Recent Applications of Heteropolyacids and Related Compounds in Heterocycles Synthesis. Mini. Rev. Org. Chem. 2009, 6, 359-366. [CrossRef]

22. Hekmatshoar, R.; Heravi, M.M.; Sadjadi, S.; Oskooie, H.A.; Bamoharram, F.F. Catalytic performance of Preyssler heteropolyacid, [NaP5W30O110]14-in liquid phase alkylation of phenol with 1-octene. Catal. Commun. 2008, 9, 837-841. [CrossRef]

23. Bamoharram, F.F.; Heravi, M.M.; Roshani, M.; Jahangir, M.; Gharib, A. Preyssler catalyst, [NaP5W30O110]14-: A green, efficient and reusable catalyst for esterification of salicylic acid with aliphatic and benzylic alcohols. Appl. Catal. A Gen. 2006, 302, 42-47. [CrossRef]

24. Ruiz, D.M.; Romanelli, G.P.; Vázquez, P.G.; Autino, J.C. Preyssler catalyst: An efficient catalyst for esterification of cinnamic acids with phenols and imidoalcohols. Appl. Catal. A Gen. 2010, 374, 110-119. [CrossRef]

25. Heravi, M.M.; Bamoharram, F.F.; Rajabzadeh, G.; Seifi, N.; Khatami, M. Preyssler heteropolyacid [NaP5W30O110]14-, as a new, green and recyclable catalyst for the synthesis of $[1,2,4]$ triazino[4,3-b] [1,2,4,5]tetrazines. J. Mol. Catal. A Chem. 2006, 259, 213-217. [CrossRef] 
26. Páez, A.; Rojas, H.A.; Portilla, O.; Sathicq, G.; Afonso, C.A.M.; Romanelli, G.P.; Martínez, J.J. Preyssler Heteropolyacids in the Self-Etherification of 5-Hydroxymethylfurfural to 5,5'-[Oxybis(methylene)]bis2-furfural Under Mild Reaction Conditions. ChemCatChem 2017, 9, 3322-3329. [CrossRef]

27. Bamoharram, F.F.; Heravi, M.M.; Ayati, A.; Baharara, J.; Jafari, A.M.; Ebrahimi, M. Acidic cesium salt of Preyssler nanoparticles: A new, green and recyclable nanocatalyst for the synthesis of 6-aryl-1H-pyrazolo[3,4d]pyrimidin-4[5H]-ones. J. Nanostructure Chem. 2014, 4, 93. [CrossRef]

28. Javid, A.; Khojastehnezhad, A.; Eshghi, H.; Moeinpour, F.; Bamoharram, F.F.; Ebrahimi, J. Synthesis of Pyranopyrazoles using a Magnetically Separable Modified Preyssler Heteropoly Acid. Org. Prep. Proced. Int. 2016, 48, 377-384. [CrossRef]

29. Tanhaei, B.; Ayati, A.; Bamoharram, F.F.; Lahtinen, M.; Sillanpää, M. A novel magnetic Preyssler acid grafted chitosan nano adsorbent: Synthesis, characterization and adsorption activity. J. Chem. Technol. Biotechnol. 2016, 91, 1452-1460. [CrossRef]

30. Rohani, M.; Bamoharram, F.F.; Khosravi, M.; Baharara, J.; Heravi, M.M. Preparation and characterisation of Preyssler heteropolyacid-cellulose acetate hybrid nanofibers: A new, green and recyclable nanocatalyst for photodegradation of methyl orange as the model dye. J. Exp. Nanosci. 2017, 12, 1-13. [CrossRef]

31. Tanhaei, B.; Ayati, A.; Bamoharram, F.F.; Sillanpää, M. Magnetic EDTA Functionalized Preyssler Cross Linked Chitosan Nanocomposite for Adsorptive Removal of Pb(II) Ions. Clean Soil Air Water 2017, 45, 1-19. [CrossRef]

32. Yadav, J.S.; Raghavendra, S.; Satyanarayana, M.; Balanarsaiah, E. Phosphomolybdic acid supported on silica gel: An efficient, mild and reusable catalyst for the chemoselective hydrolysis of acetonides. Synlett 2005, 16, 2461-2464. [CrossRef]

33. Tarlani, A.; Abedini, M.; Nemati, A.; Khabaz, M.; Amini, M.M. Immobilization of Keggin and Preyssler tungsten heteropolyacids on various functionalized silica. J. Colloid Interface Sci. 2006, 303, 32-38. [CrossRef] [PubMed]

34. Izumi, Y.; Urabe, K. Catalysis of Heteropoly Acids Entrapped in Activated Carbon. Chem. Lett. 1981, 10, 663-666. [CrossRef]

35. Bhorodwaj, S.K.; Dutta, D.K. Activated clay supported heteropoly acid catalysts for esterification of acetic acid with butanol. Appl. Clay Sci. 2011, 53, 347-352. [CrossRef]

36. Yadav, J.S.; Subba Reddy, B.V.; Srinivasa Rao, T.; Narender, R.; Gupta, M.K. PMA/SiO 2 as efficient, cost-effective and recyclable catalytic system for the synthesis of highly substituted pyrroles. J. Mol. Catal. A Chem. 2007, 278, 42-46. [CrossRef]

37. Jafari, A.A.; Mahmoudi, H.; Mirjalili, B.F. Tungstophosphoric Acid Supported on Silica Gel $\left(\mathrm{H}_{2} \mathrm{PW}_{12} \mathrm{O}_{40} / \mathrm{SiO}_{2}\right)$, Reusable and Heterogeneous Catalyst for the Synthesis of Pyrroles in Solution or under Solvent-Free Microwave Irradiation. J. Iran. Chem. Soc. 2011, 8, 851-856. [CrossRef]

38. Kumar, M.A.; Krishna, A.B.; Babu, B.H.; Reddy, C.B.; Reddy, C.S. Phosphomolybdic Acid $/ \mathrm{SiO}_{2}$ as Heterogeneous Solid Acid Catalyst for the Rapid Synthesis of $N$-Substituted Pyrroles. Synth. Commun. 2008, 38, 3456-3464. [CrossRef]

39. Villabrille, P.; Romanelli, G.; Quaranta, N.; Vázquez, P. An efficient catalytic route for the preparation of silyl ethers using alumina-supported heteropolyoxometalates. Appl. Catal. B Environ. 2010, 96, 379-386. [CrossRef]

40. Rafiee, E.; Eavani, S. Heterogenization of heteropoly compounds: A review of their structure and synthesis. RSC Adv. 2016, 6, 46433-46466. [CrossRef]

41. Wu, Y.; Ye, X.; Yang, X.; Wang, X.; Chu, W.; Hu, Y. Heterogenization of heteropolyacids: A general discussion on the preparation of supported acid catalysts. Ind. Eng. Chem. Res. 1996, 35, 2546-2560. [CrossRef]

42. Zhang, A.; Zhang, M.; Chen, H.; Chen, J.; Chen, H. Convenient Method for Synthesis of Substituted 2-Amino-2-chromenes. Synth. Commun. 2007, 37, 231-235. [CrossRef]

43. Şen, B.; Lolak, N.; Paralı, Ö.; Koca, M.; Şavk, A.; Akocak, S.; Şen, F. Bimetallic PdRu/graphene oxide based Catalysts for one-pot three-component synthesis of 2-amino-4H-chromene derivatives. Nano-Struct. Nano-Objects 2017, 12, 33-40. [CrossRef]

44. Abbat, S.; Dhaked, D.; Arfeen, M.; Bharatam, P.V. Mechanism of the Paal-Knorr reaction: The importance of water mediated hemialcohol pathway. RSC Adv. 2015, 5, 88353-88366. [CrossRef] 
45. Kharat, A.N.; Abedini, M.; Amini, M.M.; Pendleton, P.; Badalyan, A. Investigation of the Preyssler phosphotungstate heteropolyanion, [NaP5W30O110]14-, properties with different counter ions. Transit. Met. Chem. 2003, 28, 339-344. [CrossRef]

46. Jeannin, Y.; Martin-Frere, J. Inorganic Syntheses; Ginsberg, A.P., Ed.; Jhon Wiley \& Sons: Mississauga, ON, Canada, 1990; Volume 27, pp. 115-118.

47. Andraos, J. Global green chemistry metrics analysis algorithm and spreadsheets: Evaluation of the material efficiency performances of synthesis plans for oseltamivir phosphate (Tamiflu) as a test case. Org. Process Res. Dev. 2009, 13, 161-185. [CrossRef]

(C) 2018 by the authors. Licensee MDPI, Basel, Switzerland. This article is an open access article distributed under the terms and conditions of the Creative Commons Attribution (CC BY) license (http:// creativecommons.org/licenses/by/4.0/). 